\title{
The diachroneity of alluvial-fan lithostratigraphy? A test case from southeastern Ebro basin magnetostratigraphy
}

\author{
Nicholas Swanson-Hysell ${ }^{\mathrm{a}, 1}$, David L. Barbeau, Jr. ${ }^{\mathrm{b}, *, 2}$ \\ ${ }^{a}$ Geology Department, Carleton College Northfield, MN 55057, USA \\ b Department of Geological Sciences, University of South Carolina Columbia, SC 29208, USA
}

Received 25 January 2007; received in revised form 1 July 2007; accepted 3 July 2007

Available online 12 July 2007

Editor: R.W. Carlson

\begin{abstract}
Alluvial-fan strata contain valuable proxy data for kinematic, climatic and sediment-flux phenomena associated with high-relief source regions. Proper application of this data is dependent upon acquisition of accurate high-resolution chronostratigraphic data, best achieved through magnetostratigraphy. Collection of magnetostratigraphic and other proxy data from composite alluvial-fan sections assumes the chronostratigraphic significance of lithostratigraphy. We present the first test of this assumption with new magnetostratigraphy collected from Paleogene rocks of the southeastern Ebro basin. We report five new magnetostratigraphic sections that collectively sample $850 \mathrm{~m}$ of alluvial-fan and associated fluvial strata. One-hundred meters of lithostratigraphic overlap between these sections reveals equivalent magnetic polarities over short along-strike distances ( 200-2000 m). However, lithostratigraphic correlation of these sections with the magnetostratigraphy of continuously exposed strata eight km away reveals discrepancies in magnetic polarity trends and age interpretations.

Correlation of our $760 \mathrm{~m}$ composite magnetostratigraphic section with the Paleogene geomagnetic polarity time scale suggests that this section spans from ca. 31.3 to $27.7 \mathrm{Ma}(\mathrm{C} 12 \mathrm{r}-\mathrm{C} 9 \mathrm{n}$; early to late Oligocene). This correlation implies steady sedimentation rates of $\sim 12 \mathrm{~cm} / \mathrm{ka}$ for fluvial facies and $\sim 32 \mathrm{~cm} / \mathrm{ka}$ for alluvial-fan facies. Alternative interpretations that force chronostratigraphic correlation with the lithostratigraphically equivalent interval generate unsteady and/or unlikely sedimentation rates in one or both of the stratigraphies and require rejection of multiple well-constrained polarity zones. The absence of significant surfaces of erosion or paleosol development argue against these alternative interpretations and suggest that even in the best exposed study areas, alluvial-fan successions may be diachronous and preclude lateral extrapolation of chronostratigraphic and other proxy data. Interpretations and models based upon data collected from alluvial-fan strata may be tenuous unless supported by sufficient spatial overlap to constrain the relationship between time surfaces and rock surfaces.
\end{abstract}

(C) 2007 Elsevier B.V. All rights reserved.

Keywords: magnetostratigraphy; diachronous; sedimentation rate; alluvial fan; synorogenic; sequence stratigraphy; Ebro Basin; Catalan Coastal Ranges; foreland basin; Paleogene; alluvial fan; growth structure; growth strata; wedge-top

\footnotetext{
* Corresponding author.

E-mail addresses: nswanson@princeton.edu (N. Swanson-Hysell), dbarbeau@geol.sc.edu (D.L. Barbeau).

${ }^{1}$ Current address: Department of Geosciences, Princeton University, Princeton, NJ 08544, USA. Tel.: +1 6092589836.

${ }^{2}$ Tel.: +1 8037775162 .
} 


\section{Introduction}

Much of what we know about Earth history is derived from proxy records of regional and global change preserved in sedimentary rocks. Imperative to accurate collection and application of these proxy data is an understanding of the lateral and vertical relationships between strata and time in the rock record. To address this need, chronostratigraphic models have been developed and applied to marine (Vail et al., 1977; Van Wagoner et al., 1988), lacustrine (Bohacs et al., 2000; Keighley et al., 2003), fluvial (Shanley and McCabe, 1994; Currie, 1997), deltaic (Gani and Bhattacharya, 2005) and alluvial-fan strata (DeCelles et al., 1991a; Bourquin et al., 1998; Weissmann et al., 2002). Despite the elegance and utility of these models, they have only rarely been subjected to the test of independent geochronologic analysis (e.g., Vail et al., 1977; Behrensmeyer and Tauxe, 1982; Zechun et al., 1998; Prothero, 2001). Moreover, many of the models continue to be applied even after the validity of their fundamental assumptions is called into question (cf. Miall and Miall, 2000; Prothero, 2001; Dickinson, 2003). In this paper, we test the length scales of correlation between chronostratigraphy and lithostratigraphy in alluvial-fan strata, which contain proxy data that are widely applied to tectonic, climatic, and kinematic problems.

Alluvial fans are proximal depositional systems that accumulate sediments in the vicinity of high-relief source terrains and occur near the interface between drainage and depositional basins. Ancient alluvial-fan strata have been used to interpret climatic, plate tectonic, structural and autocyclic phenomena (Schumm et al., 1987; DeCelles et al., 1991a; Fraser and DeCelles, 1992; Burbank et al., 1992; Weissmann et al., 2002) and to develop influential theoretical sedimentary models (Heller et al., 1988; Blair and Bilodeau, 1988; DeCelles et al., 1991b; DeCelles and Mitra, 1995; Brozovíc and Burbank, 2000; Jones et al., 2004).

However, the cogency of such interpretations and models is often dependent upon high-resolution geochronology and the validity of assumptions used to establish the temporal relationship between data points. Alluvial fans present a challenge to both of these requirements of accurate application of proxy data. Datable volcanogenic strata are uncommon in alluvialfan successions. The high-energy deposition of alluvial fans inhibits fossil preservation, which can generate age constraints in more calm terrestrial deposystems (Woodburne, 1987). Whereas fossils from more distal lacustrine and fluvial strata can assist in the dating of proximal successions, correlations across facies boundaries are difficult to achieve with high confidence. Provided sufficient abundance of suitable lithologies, magnetostratigraphy offers an opportunity to generate detailed chronostratigraphy from alluvial-fan successions (Burbank et al., 1992; Meigs et al., 1996; Lopez-Blanco et al., 2000; Jones et al., 2004). However, the local magnetic polarity stratigraphies (LMPS) that allow correlation to the geomagnetic polarity timescale (GPTS) are often collected by combining individual sections into a composite section. This correlation technique, which is also widely applied in the collection of other proxy data from alluvial-fan and other sedimentary rocks, exploits lithostratigraphic markers that are believed to have chronostratigraphic significance. Despite elegant depositional models for alluvial-fan chronostratigraphy (Schumm et al., 1987; DeCelles et al., 1991a; Weissmann et al., 2002), the validity of this assumption remains largely untested.

Application of lithostratigraphic correlation in alluvial-fan strata requires careful stratigraphic analysis because numerous characteristics of alluvial fans may inhibit local stratigraphic completeness and prevent accurate lateral correlations required to produce complete composite sections. Point-sourced sediments, autocyclic fluctuations and extrinsic forcing common to alluvial fans instigate avulsive processes that generate spatio-temporal variations in sediment accumulation (Schumm et al., 1987; Fraser and DeCelles, 1992; DeCelles et al., 1991a; Weissmann et al., 2002). The entrenchment and backfilling processes associated with alluvial-fan deposition (Schumm et al., 1987) can also result in erosion of previously deposited strata leading to further stratigraphic incompleteness. Variations in thrust-belt structural style and kinematic history can introduce along-strike age gradients in synorogenic strata (Butler et al., 2001; Nichols, 2002). Growth structures, which are common in alluvial-fan strata, often contain local intraformational unconformities (Anadón et al., 1986; DeCelles et al., 1991b; Lawton et al., 1999; Barbeau, 2003). Despite these hazards, numerous researchers have utilized alluvial-fan magnetostratigraphy to develop sedimentary histories and theoretical models by assuming lateral continuity and chronostratigraphic significance of proximal strata.

In this paper, we integrate new and existing magnetostratigraphic data with sedimentology and field mapping of a well-exposed Paleogene alluvial-fan succession adjacent to the Catalan Coastal Ranges (CCR) in the southeastern Ebro basin (Spain) in order to examine the synchronicity of alluvial-fan lithostratigraphy and magnetostratigraphy. We achieve these goals through the evaluation of candidate correlations of two 
composite LMPS to the GPTS in light of resultant sedimentation rates and stratigraphic architecture.

In addition to providing important tests of the efficacy of lithostratigraphic correlations and interpretations within proximal strata, this study attempts to use the new magnetostratigraphic dataset to constrain ages of CCR wedge-top deposition in the southeastern Ebro basin. Since the succession records tectonic activity along the eastern margin of Iberia, this new correlation provides valuable insight into the kinematics of the pre-rollback history of the western Mediterranean and the relative synchronicity of deformation in the CCR and the Pyrenees (Fig. 1).

\section{Geologic setting}

\subsection{Plate tectonics, thrust belts and basin formation}

The Ebro basin formed concurrently with uplift and crustal shortening attributed to the Late CretaceousPaleogene collision of Iberia with western Europe and deformation in the Pyrenean, Iberian and CCR of northeastern Spain (Anadón et al., 1986; Lopez-Blanco, 2002). This deformation was partly coincident with $35^{\circ}$ of anticlockwise rotation that translated the Iberian Peninsula from its Cretaceous position west of France to its current location via rotational opening of the Bay of Biscay (Srivastava et al., 1990; Roest and Srivastava, 1991).

The formation of the Ebro basin is attributed to loading and sediment flux caused by shortening and uplift in the Pyrenees (Zoetemeijer et al., 1990; Muñoz, 1992; Fitzgerald et al., 1999), which began in the Late Cretaceous and continued into the Late Oligocene or Early Miocene (Meigs et al., 1996; Hogan and Burbank, 1996; Arenas et al., 2001). Although the Pyrenees have been the focus of Iberia-Europe convergence, broadly coeval deformation is recorded by cross-cutting relationships and growth strata in the CCR (Anadón et al., 1985, 1986; Lawton et al., 1999), and suggests a complicated Paleogene deformational regime in northern Iberia. The CCR may have developed contemporaneously with the Pyrenees (Zoetemeijer et al., 1990; García-Castellanos et al., 2003) by intraplate deformation along pre-existing crustal weaknesses associated with Mesozoic rift-basins (Gaspar-Escribano et al., 2004). Alternatively, the CCR may have developed in response to strain-hardening as Iberia sutured to Eurasia along the Pyrenean zone, causing shortening to jump southward (Schettino and Turco, 2006).

Rejuvenated attention to post-Oligocene extension in the western Mediterranean caused by eastward retreat of a west-dipping Paleogene subduction zone (Lonergan and White, 1997; Wortmann et al., 2001; Rosenbaum et al., 2002; Schettino and Scotese, 2002) requires consideration of antecedent convergent events along the eastern Iberian margin in the vicinity of the CCR. The significance of the CCR with respect to Iberia-Europe convergence, and subduction beneath eastern Iberia is not well constrained, making proxy records of this deformation particularly important.

\subsection{Stratigraphy and structural geology}

Paleogene alluvial-fan and associated strata are exposed for $200 \mathrm{~km}$ along the western flank of the central and southern CCR (Fig. 1). Northeast of the Ebro River, these strata are composed of deposits from four large fan systems that distributed coarse-grained sediment $7-25 \mathrm{~km}$ into the basin from the mountain front. Coeval fluvial-lacustrine strata intervene the Sant Llorenç del Munt, Montserrat, Sant Miguel del Montclar and Montsant fan systems (Fig. 1) and delineate their margins. Southwest of where the Ebro River intersects the CCR, a $\sim 60 \mathrm{~km}$ long, 1-4 km wide belt of coarsegrained proximal strata flank the southern CCR. This coarse-grained belt is narrower and more continuous than the belt northeast of the Ebro River, suggesting that the southern segment formed via coalescence of numerous small fans, whereas sedimentation to the northeast occurred in larger, discrete fan systems (Anadón et al., 1989). Due to the similar source lithologies along the length of the southern CCR, the boundaries of individual fans have not been delineated.

This study compiles and compares magnetostratigraphic data collected from a particularly well-exposed section of the southern segment near the 'Linking Zone' (Guimerà, 1984) that forms the transition between the CCR and the Iberian Ranges (Fig. 1). The early (?) Paleogene fluvial and lacustrine strata below and in the lower part of the study interval are commonly referred to as the Cornudella Formation (López et al., 1985; Lawton et al., 1999), although the temporal relationship with its type locality in the central CCR is not well-documented. Alluvial-fan conglomerates in overlying gradational contact with the Cornudella Formation compose the Montsant Formation, although the relationship of these strata with the type Montsant Formation conglomerates in the central CCR (Fig. 1) is also not well-constrained.

The lower Cornudella Formation consists of paleosols, lacustrine marls and fine-grained fluvial overbank strata deposited atop Cretaceous marine carbonates. The upper Cornudella Formation is composed of fluvial channel sandstones, overbank mudstones and fine sandstones, and subordinate channel conglomerates. The Montsant Formation is composed of alluvial-fan cobble- 
pebble conglomerates with subordinate sandstones and siltstones. Stratigraphic thickness variations and upsection dip decreases in the upper Montsant Formation of the Rodamunts region (Figs. 2 and 3) indicate syntectonic deposition of growth strata with deposition occurring above a fault-propagation fold (Barbeau, 2003). Growth strata and associated progressive unconformities have been recognized in similar deposits to the SW and NE of Rodamunts (Anadón et al., 1986; Lawton et al., 1999; Lopez-Blanco, 2002).

We report new magnetostratigraphic data from the uppermost Cornudella and Montsant Formations between Rodamunts and Muntanya de Santa Bàrbara (Figs. 2 and 3) for comparison with composite magnetostratigraphic sections (Jones, 1997; Jones et al., 2004) reported from broadly equivalent strata to the north and northeast that were deposited by interfingering of the GuadalopeMatarranya fluvial system and multiple alluvial fans of the Horta-Gandesa alluvial system.

\section{Previous magnetostratigraphic work in the southeastern Ebro Basin}

Barberà et al. (2001) constructed a magnetobiostratigraphy from diverse stratigraphic sections in the medial part of the eastern Ebro Basin to the northeast of the study area (Fig. 1). Using the magnetostratigraphy of lacustrine and distal fluvial strata and 53 fossil mammal sites ascribed to local biozones and/or European reference levels, they interpreted the intermediate to

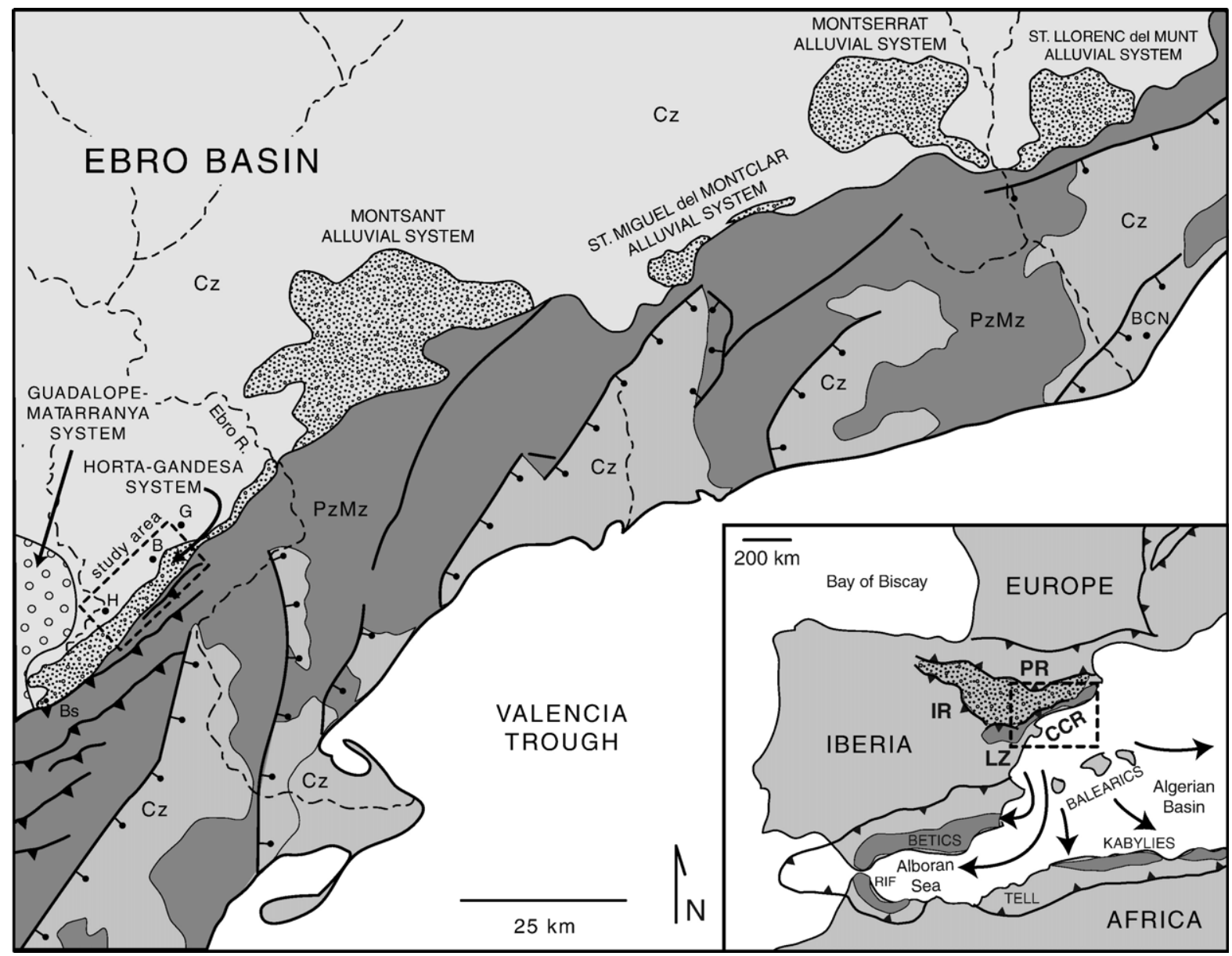

Fig. 1. Geologic setting. Inset: map of the Iberian Peninsula showing the location of the Pyrenees (PR), Iberian Ranges (IR), Catalan Coastal Ranges (CCR), Linking Zone (LZ) and the now-dispersed Paleogene orogenic belts of the Greater Iberian thrust system (Lonergan and White, 1997; Rosenbaum et al., 2002). Main figure: Eastern Ebro basin and CCR depicting the location of the study area relative to (a) the four major Paleogene alluvial-fan systems of the northeastern CCR, and (b) the changing orientation and structural style of the CCR. PzMz: Hercynian metasedimentary and granitic rocks overlain by Mesozoic strata of the Maestrat basin (Lawton et al., 1999), inverted to form the CCR. Cz: Cenozoic strata of the Ebro basin and strata associated with the opening of the Valencia Trough. Cities and towns:- H: Horta de Sant Joan, B: Bot, G: Gandesa, Bs: Beseit, BCN: Barcelona. 
marginal facies of the partially exposed Montsant alluvial system to have been deposited from 34.8 to 23.7 Ma (late Eocene to early Miocene). The individual magnetostratigraphic and lithostratigraphic sections reported in Barberà et al. (2001) are plotted herein with respect to the Cande and Kent (1995) GPTS (heretofore CK95; Fig. 4), and reveal nearly constant undecompacted net sediment accumulation rates of $\sim 16 \mathrm{~cm} / \mathrm{ka}$ $\left(R^{2}=0.99\right)$, irrespective of depositional system. The integration of magnetostratigraphic and biostratigraphic data makes this effort the most robust and detailed geochronology of Paleogene southeastern Ebro foreland basin stratigraphy to date.

Lopez-Blanco et al. (2000) reported a LMPS collected from alluvial-fan strata of the Montserrat fan-delta system of the central CCR (Fig. 1). Superpositional, biostratigraphic and eustatic sea-level arguments support a middle Eocene age making this fan system older than the alluvialfan strata of the southern CCR examined in this study. The section's LMPS and interpreted correlation with the CK95 GPTS is presented herein for comparative purposes (Fig. 4).

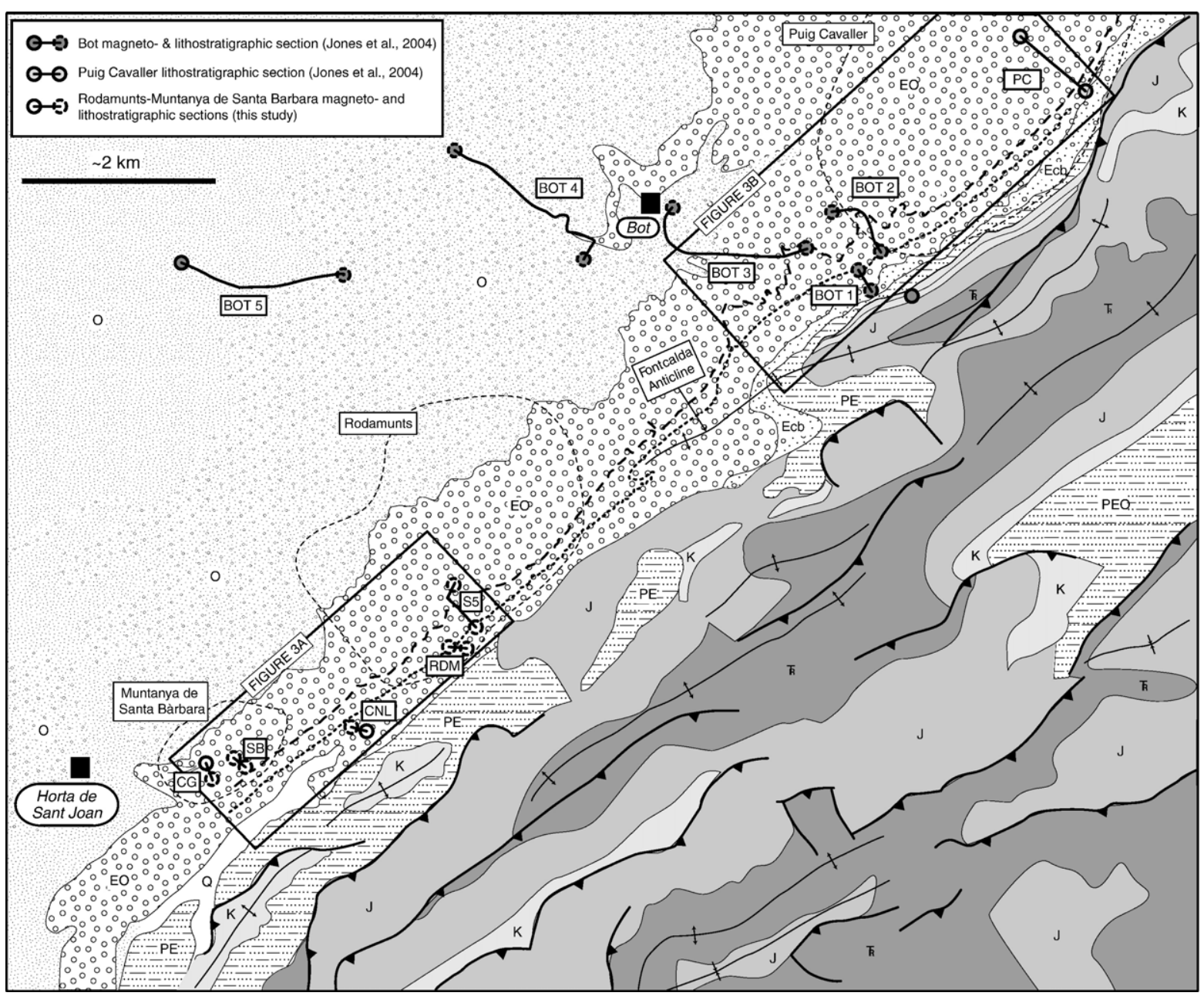

Fig. 2. Simplified geologic map of the southwestern CCR and southern Ebro basin near Horta de Sant Joan and Gandesa, Catalunya. Formation distribution from López et al. (1985); alluvial-fan lithosomes from Barbeau (2003). Paleomagnetic transects BOT1-5 are corrected locations from Jones et al. (2004), provided by Miguel Garcés (pers. comm., 2006). Location map shown in Fig. 1. The two thick dotted and dashed lines mark lithostratigraphic correlation between the Puig Cavaller (PC), Bot (BOT1, etc.) and Rodamunts-Muntanya de Santa Bàrbara sections (S5, RDM, CNL, SB, CG). TR: undivided Triassic marine carbonates and shales; J: undivided Jurassic marine carbonates; K: undivided Cretaceous marine carbonates; PE: undivided Paleocene-Eocene terrestrial mudstones, sandstones and marls; PEO: undivided Paleocene-Oligocene terrestrial mudstones and sandstones; Ecb: Bartonian terrestrial sandstones and mudstones. [PE, PEO and Ecb are generally known as the Cornudella Formation.] EO: undivided Eocene-Oligocene alluvial-fan conglomerates and subordinate sandstones generally known as the Montsant Formation; $\mathrm{O}$ : Rupelian and Chattian sandstones and conglomerates that are medial-basin strata of the Guadalope-Matarranya fluvial system intercalated with distal strata of the Montsant Formation alluvial fan deposystem. Q: Quaternary alluvium. 


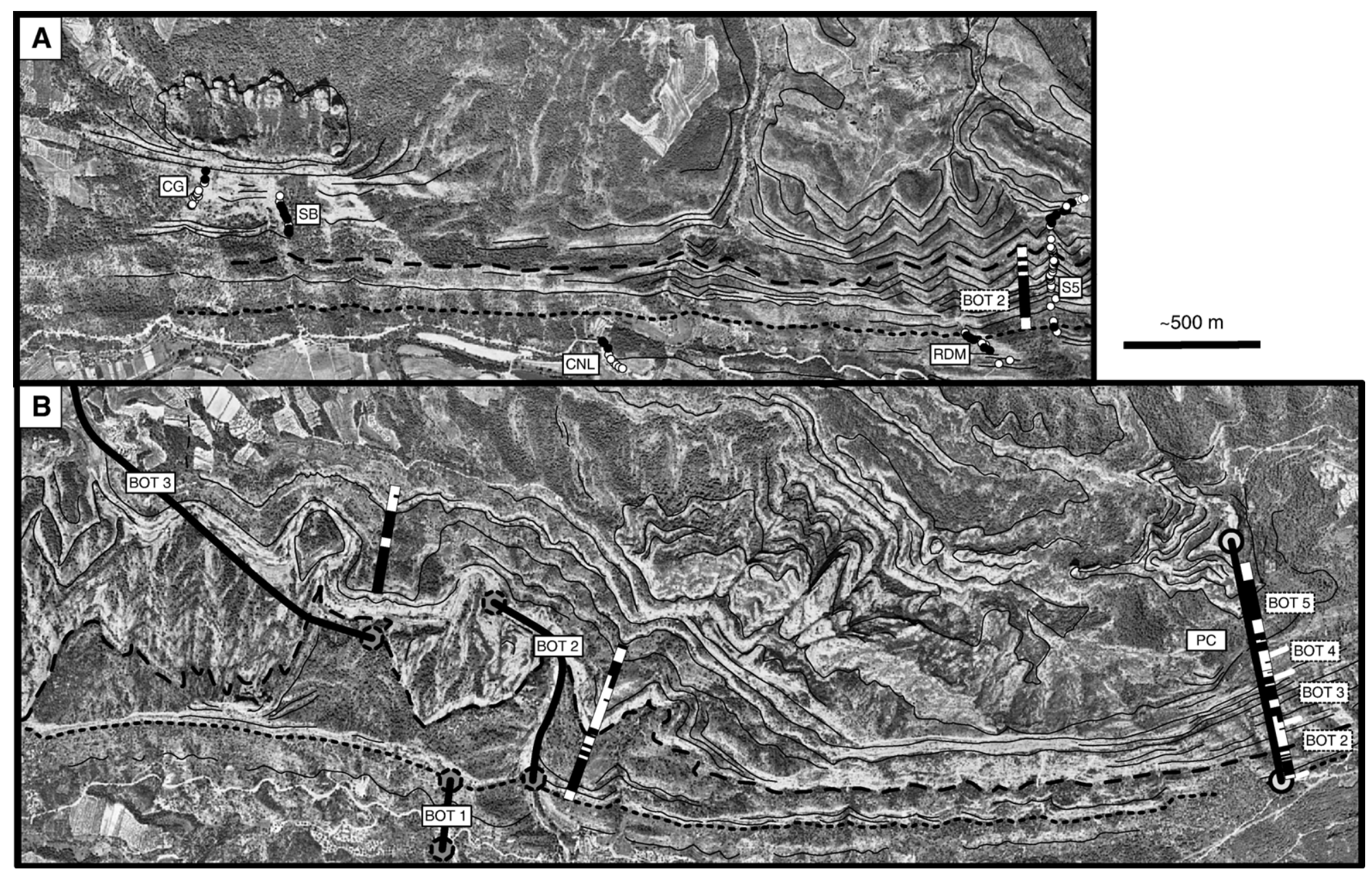

Fig. 3. Ortho-rectified and annotated aerial photos of the Rodamunts-Muntanya de Santa Bàrbara (A) and Puig Cavaller area (B) study regions. Location of maps shown in Fig. 2. The two thick dotted and dashed lines mark the lithostratigraphic correlation between the Puig Cavaller (PC), Bot (BOT 1, etc.) and Rodamunts-Muntanya de Santa Bàrbara sections (S5, RDM, CNL, SB, CG). Thin solid lines mark lithosome boundaries, but are not continuous between the two study areas. Circles in A represent magnetostratigraphic sample sites collected in this study and their corresponding magnetic polarity. Local magnetic polarity columns in B are from Jones et al. (2004) and are stretched to match lithosome interpretations in their Fig. 2 and the corrected transect locations (Miguel Garcés, pers. comm., 2006). Local magnetic polarity columns (labeled with dashed BOT 2,-BOT 5 polygons) adjacent to the Puig Cavaller lithostratigraphic section (PC) in B represent projections made by Jones et al. (2004) depicted in Fig. 5. Local magnetic polarity column labeled with dashed BOT 2 polygon in A represents lithostratigraphic projection of the lower half of the BOT 2 LMPS whose data was collected by Jones et al. (2004) from the transect labeled in B. Note resulting discrepancies in LMPS suggesting that long-distance (>2 km) lithostratigraphic correlations of alluvial-fan strata may not be chronostratigraphically equivalent. 


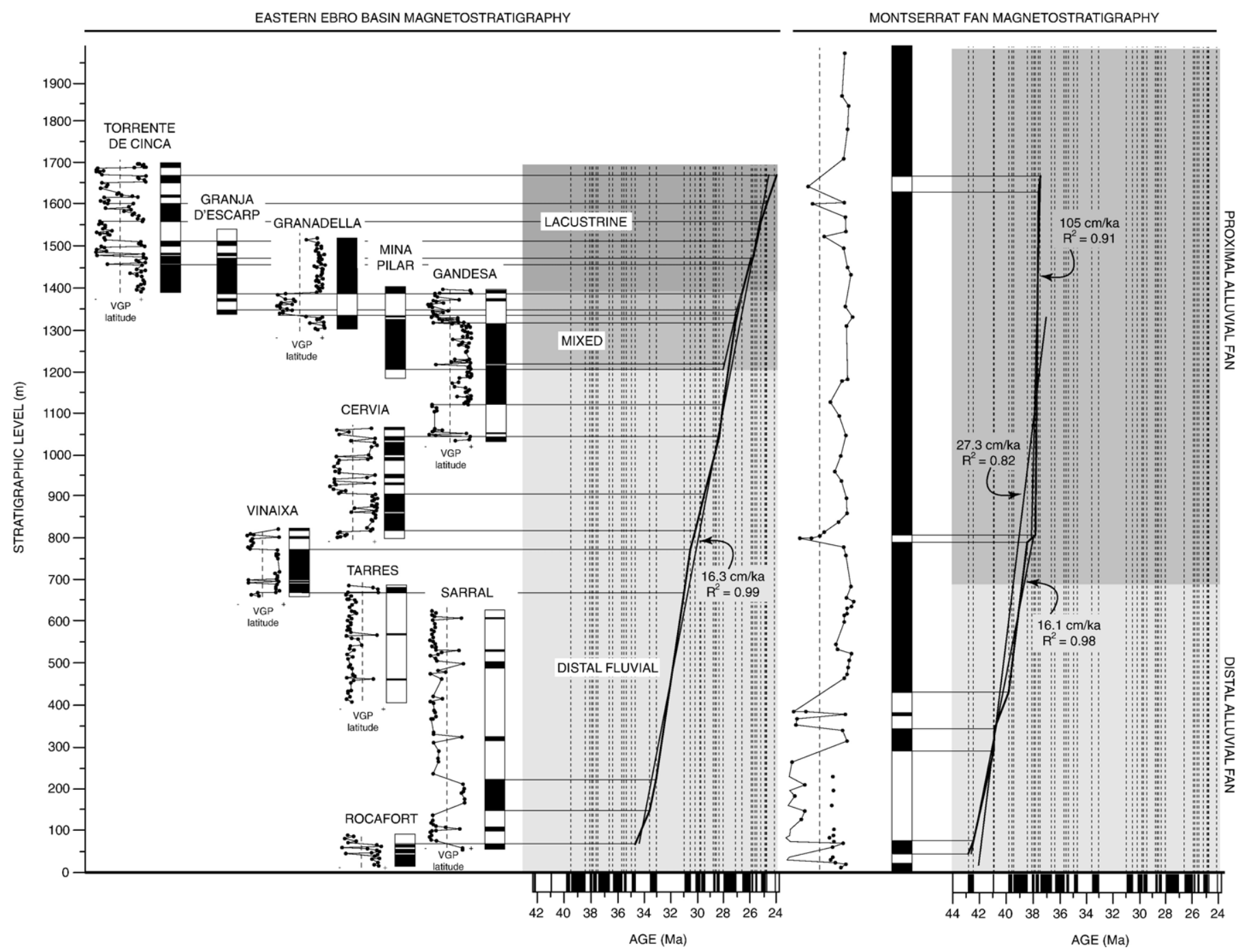

Fig. 4. Calculation of net sediment accumulation rates from compilation of magnetostratigraphic data from fluvial and lacustrine strata of the distal part of the eastern Ebro Basin (Barberà et al., 2001), and from alluvial-fan strata of the Montserrat fan-delta of the northern CCR (Lopez-Blanco et al., 2000). The Montserrat LMPS has a $20 \mathrm{~m}$ average vertical sampling interval with numerous gaps exceeding $50 \mathrm{~m}$. Biostratigraphically constrained late Bartonian evaporites of the Cardona Formation correlate to a position stratigraphically above the Montserrat fan-delta. With this constraint, their LMPS suggests deposition between ca. 43 and $37 \mathrm{Ma}$ with $\sim 16 \mathrm{~cm} / \mathrm{ka}\left(R^{2}=0.98\right)$ net sediment accumulation rate in the lower section that accelerates to more than $100 \mathrm{~cm} / \mathrm{ka}\left(R^{2}=0.91\right)$ in the upper section. Because of the small number of polarity intervals used to constrain the net sediment accumulation rate of the upper section, we also report the $\sim 27 \mathrm{~cm} / \mathrm{ka}$ average net sediment accumulation rate for the entire succession but note its relatively low coefficient of determination $(0.82)$. 
Jones (1997) reported a LMPS collected from a transect southeast of the town of Bot (Figs. 1-3). She presented two possible correlations to the GPTS based on two biostratigraphic considerations: (1) Projection of a fossil site containing Eomys zitteli fauna near the town of Gandesa, which at the time of publication was dated at ca. $27 \mathrm{Ma}$ (Agustí et al., 1988), near the top of the C9n chron (Cande and Kent, 1995). (2) An early-middle Eocene (ca. 37-40 Ma) charophyte assemblage reported elsewhere in the upper part of the Cornudella Formation (Cabrera et al., 1985) that she correlated with the lower part of the studied section. Because of its low sampling density, and the improvements made in Jones et al. (2004), the LMPS of Jones (1997) is not presented nor evaluated further herein.

Jones et al. (2004) resampled and reanalyzed the magnetostratigraphy of a similar interval at a higher density than was reported in Jones (1997) and added an additional overlying section of interfingering deposits of the Guadalope-Matarranya fluvial system (Fig. 5, Anadón et al., 1989; Jones, 1997; Jones et al., 2004), which composes a fundamentally different depositional system that debouched sediment into the southern Ebro basin near the Linking Zone-CCR syntaxis $\sim 50 \mathrm{~km}$ to the southwest (Anadón et al., 1986, 1989). This effort resulted in a significantly different LMPS that Jones et al. used to reinterpret short-term variations in sedimentation rates without diverging from the previous overall age range of the foreland basin succession (ca. 40 to $27 \mathrm{Ma}$ ). As in Jones (1997), Jones et al. (2004) projected onto their section the E. zitteli fossil site near Gandesa, but neglected to utilize the updated chronostratigraphy of Barberà et al. (2001) that assigned the fossil site to the top of chron C10n, which occurs at ca. $28 \mathrm{Ma}$ in the CK95 GPTS. As a result, Jones et al. (2004) anchored their correlation to the top of C9n (ca. $27 \mathrm{Ma}$ ). To constrain the base of their LMPS, Jones et al. used the early-middle Eocene charophyte fossil assemblage (Cabrera et al., 1985; Anadón et al., 1992) found elsewhere in the upper strata of the Cornudella Formation's fluvio-lacustrine system, but acknowledged that the gradational contact between the Cornudella and Montsant Formations make the projection of this fossil locality difficult. Jones et al.'s

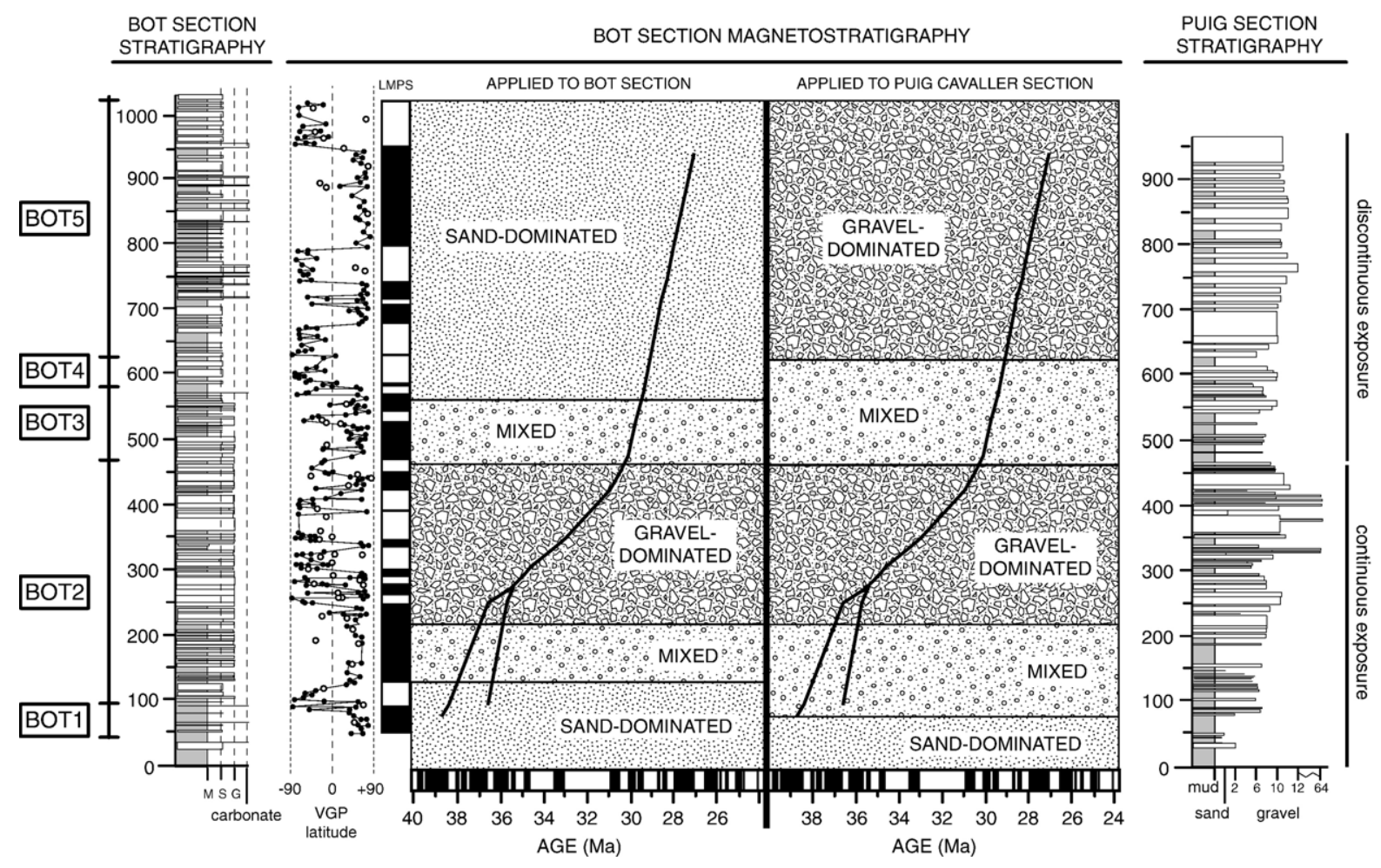

Fig. 5. Comparison of 'Bot Section' and 'Puig Cavaller' section lithostratigraphies with the Bot section magnetostratigraphy of Jones et al. (2004). A correlation of the magnetostratigraphic data collected from the intercalated Guadalope-Matarranya fluvial system of the Bot section was used to interpret the sediment accumulation history of the Puig Cavaller section (Fig. 8 of Jones et al., 2004). Stratigraphic position of individual magnetic transects BOT1-BOT 5 shown in Fig. 2 and Fig. 3 are depicted at left of Bot lithostratigraphy (Garcés, pers. comm., 2006). Note the dramatically different architectures of the two sections, reflecting the influence of the Guadalope-Matarranya fluvial system in the Bot section stratigraphy. The increase in sedimentation rate at $\sim 450$ m coincides with a dramatic decrease in the fraction of coarse-caliber sediment. All data from Jones et al. (2004). 
resulting correlation of their LMPS to the CK95 GPTS yields net sediment accumulation rates of $\sim 3 \mathrm{~cm} / \mathrm{ka}$ and $\sim 16 \mathrm{~cm} / \mathrm{ka}$ for the middle and upper parts of their section, respectively. Ambiguity of the lower part of the LMPS led them to suggest two comparatively high $(\sim 10-20 \mathrm{~cm} / \mathrm{ka})$ sediment accumulation rate interpretations.

\section{Results}

We report new paleomagnetic data (Fig. 6 and Fig. 7) from five sections that transect Rodamunts and Muntanya de Santa Bàrbara (Fig. 2, Fig. 3 and Fig. 7), which we compile into a single composite section (RMSB LMPS) covering a net $\sim 770 \mathrm{~m}$ of strata (Fig. 7). The analyzed samples were collected from red siltstone and fine sandstone intervals of the conglomeratic study interval. The methods of sample collection and analysis are included as supplementary material in the online version.

\subsection{Components of remanent magnetism}

The intensity of the natural remanent magnetization (NRM) was between $2.6 \times 10^{-2}$ and $5.2 \times 10^{-5} \mathrm{~A} / \mathrm{m}$ for all samples. Alternating field (AF) demagnetization and the first steps of thermal demagnetization usually removed a component with present local field (PLF) direction (Fig. 6). The vector component removed by AF demagnetization steps $(0-10 \mathrm{mT})$ was usually slight, but almost always parallel to the PLF direction. The first steps of thermal demagnetization $\left(100^{\circ}\right.$ and $\left.150^{\circ} \mathrm{C}\right)$ also removed an occasionally large PLF overprint (Fig. 6).

Vectors removed during the first steps of thermal demagnetization are dispersed around the PLF before correction for bedding tilt (Fig. 6). Bedding dips in the studied section vary from $30^{\circ}$ to $70^{\circ}$. As such, comparison of Fisher statistics from pre-and post-correction bedding constitutes a fold test. The PLF overprint vectors fail the McElhinny (1964) fold test as the Fisher concentration parameter $(k)$ is maximized at $0 \%$ unfolding -indicating that these directions constitute a post-tectonic overprint.

Some specimens became directionally unstable above low or mid-range temperatures, but many exhibit a high unblocking temperature component that was removed above $600{ }^{\circ} \mathrm{C}$ (Fig. 6). This component, interpreted as the characteristic remanent magnetism (ChRM), decayed towards the origin. Least-squares fit lines were fit to the data yielding resultant ChRM vectors with both normal and reversed polarities. These vectors pass the McElhinny (1964) fold test at 99\% confidence as they become significantly more concentrated upon correction for bedding orientation $\left(k_{1} / k_{2}=2.24\right.$; Fig. 6$)$. The populations of reversed and normal directions are distinguishable and, while roughly antiparallel, the mean vectors have significant differences in declination resulting in an inconclusive reversal test. Differences in declinations between normal and reverse polarity mean ChRM directions have also been observed in other Ebro basin magnetostratigraphies, including those from Eocene turbidites (Oms et al., 2003), Eocene mixed carbonate and clastics (the Vic section of Burbank et al., 1992), and Oligocene fluvial strata (Turner et al., 1984) in the Pyrenees, and from Eocene alluvial-fan (Lopez-Blanco et al., 2000), and Oligo-Miocene fluvio-lacustrine strata (Barberà et al., 1994) in the CCR. The ChRM directions of these results do not vary systemically through our studied section, suggesting that vertical-axis rotation is not a tenable explanation for these declination variations.

\subsection{Magnetic stratigraphy}

Local magnetic polarity stratigraphies (Fig. 7) were constructed for the individual sections based on the virtual geomagnetic pole (VGP) latitudes calculated from tilt-corrected ChRMs of Type I data (e.g., Fig. 6). Correlation between the combined $\sim 865 \mathrm{~m}$ of section analyzed in the CNL, RDM, S5, SB and CG sections yields a $770 \mathrm{~m}$ thick composite LMPS (Fig. 7) containing 15 reversals. Where individual sections overlap via lithostratigraphic correlation the polarity zones are coincident (e.g., RDM with S5, SB and CG with S5). This agreement of reversals in nearby lithostratigraphically correlated sections reinforces the robustness of the local $(<100 \mathrm{~m})$ correlations and of the LMPS itself.

\section{Interpretation and discussion}

\subsection{Correlation with the global polarity time scale}

As in other proximal depozones (Colombo, 1994; Lawton et al., 1999; Lopez-Blanco et al., 2000; LopezBlanco, 2002), neither fossils nor volcanogenic strata have been identified in the immediate study area. Despite the absence of independent age constraints, robust evidence brackets the depositional age of the studied interval to the Paleogene period: (1) Paleocene and Eocene gastropod, ostracode and charophyte (López et al., 1985; Anadón et al., 1992) and Oligo-Miocene mammal faunal assemblages (Agustí et al., 1988; Barberà et al., 2001) occur in intercalated and overlying strata and their interpreted equivalents, respectively. (2) The Cornudella Formation, which shares a gradational relationship and compositional similarities with the overlying Montsant Formation that comprises the 
majority of the studied interval, is superposed on Upper Cretaceous marine carbonates southeast of the study area. (3) Growth strata in the studied interval (Barbeau,
2003 ) and its equivalents to the northeast and southwest (Anadón et al., 1986, 1989; Lawton et al., 1999; Jones et al., 2004) are consistent with north-south Paleogene

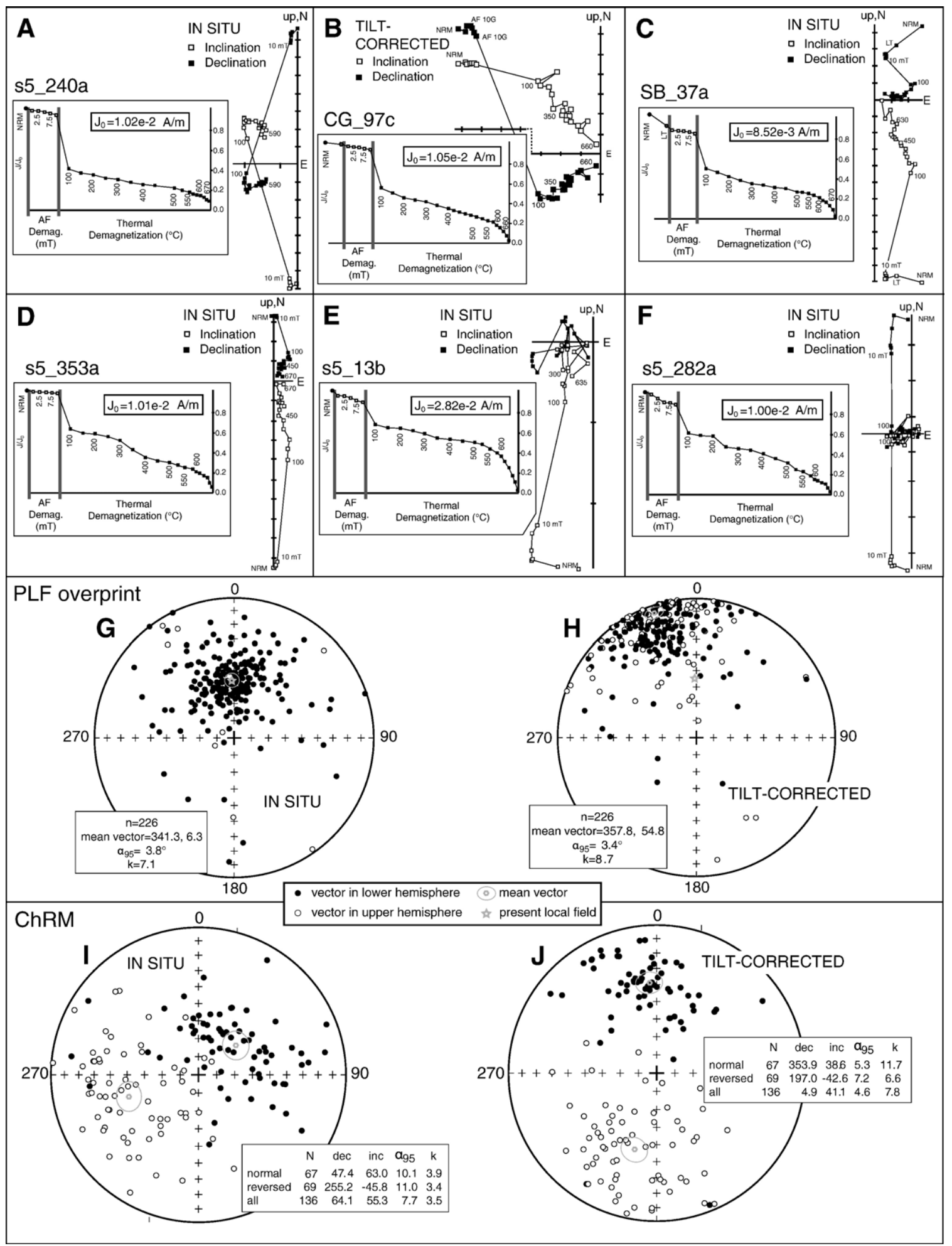


convergence and shortening independently recognized in Iberian-Eurasian-African plate reconstructions (Srivastava et al., 1990; Roest and Srivastava, 1991; Rosenbaum et al., 2002), and Paleogene cooling ages in the Pyrenees and the greater Iberian thrust system (Monié et al., 1991; Rosseti et al., 1999; Rosenbaum et al., 2005), and (4) Latest Oligocene-Neogene extensional basins crosscut the CCR and mark the change from convergent to extensional tectonics that now dominate the northeastern Iberian margin (López et al., 1985; Roca et al., 1999).

Considering these ages, we have correlated the RMSB LMPS (Figs. 8 and S1) to the Paleogene GPTS. Given the lack of evidence for major hiatus, pedogenesis and/or erosion in the studied interval and the sedimentation rates determined from a robust magnetobiostratigraphy of broadly coeval, but distal, southeastern Ebro basin lithofacies (Barberà et al., 2001), we sought a correlation that would yield sedimentation rates that were (a) internally steady within the upper and lower parts of the studied succession on $10^{5}-10^{6}$ year timescales, and (b) consistent with the expected increase in sedimentation rate caused by progradation of large sediment-flux, proximal (alluvial-fan) strata atop low sediment-flux, more distal (fluvial) strata and the increase in flexural subsidence that accompanies northwestward propagation of the CCR orogenic wedge (Lopez-Blanco et al., 2000).

Our proposed correlation of the composite RMSB LMPS to the CK95 and OS04 (Ogg and Smith, 2004) GPTS is shown in Fig. 8A. This correlates the RMSB section to chrons $\mathrm{C} 12-\mathrm{C} 9$ in the early to late Oligocene (31.3 to 27.7 Ma for CK95; 31.5 to 27.6 Ma for OS04). For this correlation to work, two normal polarity zones based on single data points must be ignored. Due to the nature of viscous remagnetization, a normal polarity data point is less reliable than one of reversed polarity because of the propensity for PLF overprints to disguise reverse polarities if a sample is only moderately stable at higher temperatures. Other than these discrepancies, the fit between the LMPS and the GPTS is straightforward.

Because our preferred correlation of the RMSB LMPS to the GPTS conflicts with that of Jones et al. (2004), we made four alternative correlations, which are presented in Fig. S1 in the online version. We evaluate the apparent conflicts of these correlations in Section 5.3 as well as Table S1 in the online version.

\subsection{Sedimentation rates}

Our preferred correlation of the RMSB LMPS to the CK95 GPTS yields a significant change in vertical sediment accumulation rates at 29.6 Ma (29.7 Ma for OS04). Average undecompacted net sediment accumulation rates for the fluvial-dominated upper Cornudella and the alluvial-fan dominated Montsant Formations are $\sim 12 \mathrm{~cm} / \mathrm{ka}\left(R^{2}=0.94\right)$ and $\sim 32 \mathrm{~cm} / \mathrm{ka}\left(R^{2}=0.98\right)$, respectively, and reflect the increased sediment flux characteristic of alluvial fan systems.

The magnitudes and up-section increase in sediment accumulation rates are consistent with previous work in the Ebro basin and in the terrestrial deposystems and proximal depozones of other settings. The magnetobiostratigraphy reported in Barberà et al. (2001) composes the highest resolution chronostratigraphy in the southeastern Ebro basin to date and yields a steady sedimentation rate of $\sim 16 \mathrm{~cm} / \mathrm{ka}$ throughout the studied distal fluvial and lacustrine strata accumulated in the medial basin between ca. 35 and $24 \mathrm{Ma}$ (Fig. 4). Although less well-constrained and of lower resolution than the data of Barberà et al. (2001), magnetostratigraphy from the early-middle Eocene Montserrat fan-delta system of the central CCR (LopezBlanco et al., 2000; Lopez-Blanco, 2002) reveal sedimentation rates of $\sim 16 \mathrm{~cm} / \mathrm{ka}$ for interbedded distal alluvial-fan and fluvial strata increasing to $\sim 20-100 \mathrm{~cm} / \mathrm{ka}$ for proximal alluvial fan-strata (Fig. 4). In his study of more than 25,000 sedimentation rates, Sadler (1981) determined that when constrained via techniques with $10^{5}-10^{6}$ year

Fig. 6. Representative vector component diagrams (Zijderveld, 1967), and magnetic intensity $\left(J / J_{0}\right)$ plots showing demagnetization behavior for representative samples from the RMSB section. Plots A, B, C and D are of specimens for which the characteristic remanent magnetism (ChRM) could be conclusively determined (Type I data). When not corrected for bedding the component removed during AF demagnetization and the large component removed by the first thermal demagnetization step corresponds with the present local field (PLF). Vectors that can be fit by principal component analysis (Kirschvink, 1980) through mid-to-high temperature points to the origin are the ChRMs: reversed polarity for A and B and normal polarity for C and D. Plots $\mathrm{E}$ and $\mathrm{F}$ are of specimens for which no ChRM could be conclusively determined. Results shown in E are indicative of Type II data due to an ambiguous trend towards the origin and questionable polarity. Results shown in F constitute a Type III data point as no ChRM can be determined. Equal area projections $\mathrm{G}$ and $\mathrm{H}$ show directions of the vectors that were removed during the first steps of thermal demagnetization $\left(10 \mathrm{mT}-100^{\circ} / 150^{\circ} \mathrm{C}\right)$. The mean vector in geographic (in situ) coordinates is indistinguishable from the PLF direction $(358.2,56)$. The concentration factor $(k)$ of these vectors is highest before any bedding correction is applied such that the data fails the McElhinny (1964) fold test. This indicates that this low-coercivity component of the magnetization was acquired as a post-tectonic overprint. Plots I and $\mathrm{J}$ are in situ and tilt-corrected equal-area projections of all Type I ChRM directions. These directions pass a fold test $\left(k_{1} / k_{2}=2.24\right.$; McElhinny, 1964) at the $99 \%$ confidence level when corrections are made for bedding tilt, indicating that these vectors are a primary magnetization. 


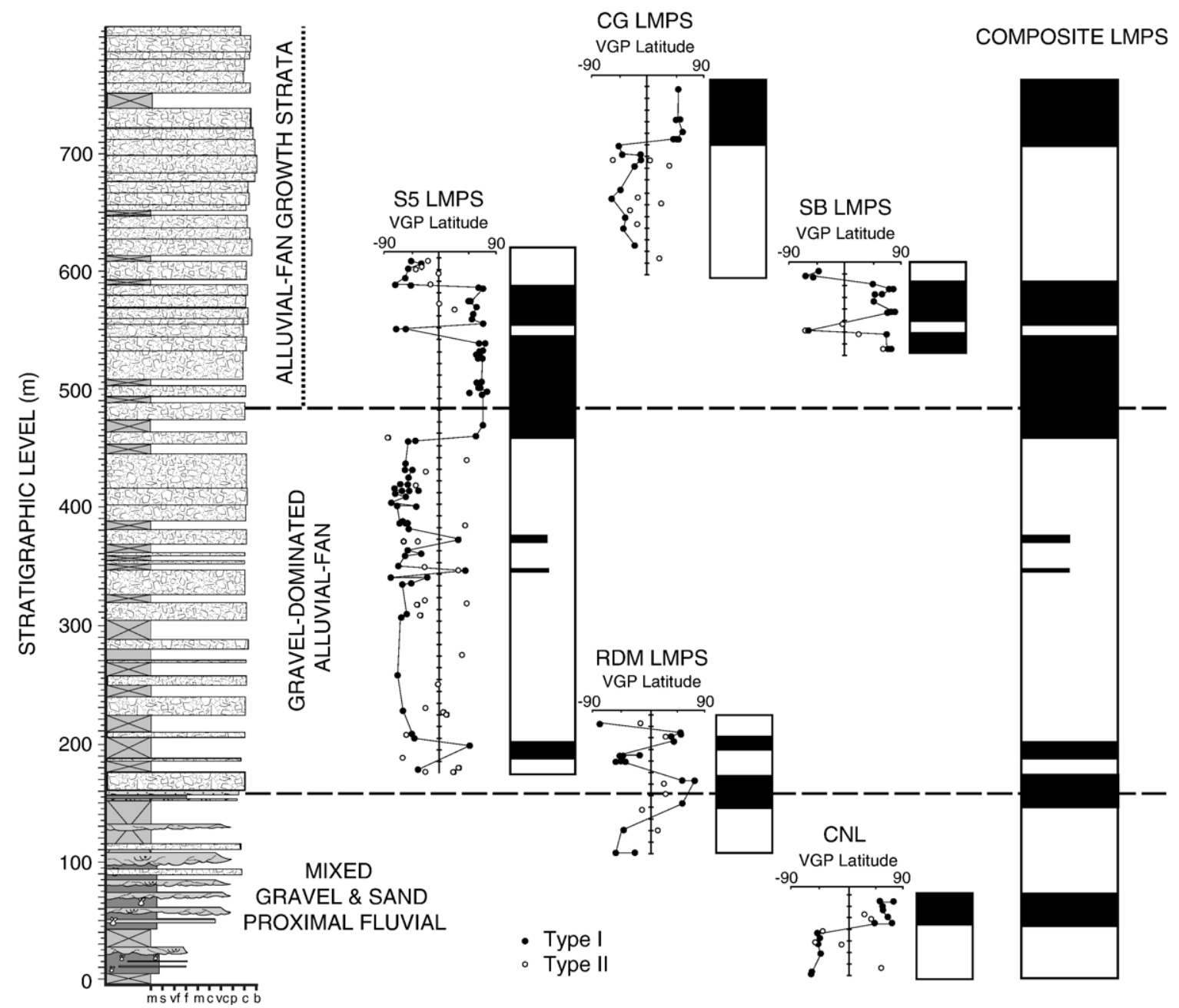

Fig. 7. Lithostratigraphy and composite local magnetic polarity stratigraphy (LMPS) of Rodamunts and Muntanya de Santa Bàrbara (RMSB) constructed using lithostratigraphic correlations of the individual LMPS sections: CNL, RDM, S5, SB and CG. Virtual geomagnetic pole (VGP) latitudes calculated from ChRM directions are used to develop the normal and reversed polarity zones for the individual LMPS sections. Negative VGP latitudes correspond with reversed polarity zones (white); positive VGP latitudes correspond with normal polarity zones (black). Whereas both Type I and II data are presented (closed and open circles respectively), only the Type I points were used to develop the LMPS. Half-width polarity zones indicate that the zone is supported by only one data point.

age-resolution (as is tenable in Paleogene magnetostratigraphy), fluvial sedimentation rates range $\sim 5-100 \mathrm{~cm} / \mathrm{ka}$, with a mean value of $\sim 10 \mathrm{~cm} / \mathrm{ka}$.

\subsection{Correlation to previous magnetostratigraphic work}

Whereas our preferred correlation between the RMSB LMPS and the GPTS falls within the age range interpreted for broadly equivalent strata in the Puig Cavaller area $\sim 10 \mathrm{~km}$ to the northeast (Jones et al., 2004), it conflicts fundamentally with that interpretation (Figs. 8, S2A). Moreover, a 250-meter interval in the lower part of the RMSB S5 section contains a polarity stratigraphy that does not match that collected from a lithostratigraphically traceable interval from the PC LMPS (Fig. 2 and Fig. 3).

As a result of these discrepancies, we present four alternative interpretations of our LMPS (Figs. S1B-E, 8) and six alternative interpretations of the Jones et al. Puig Cavaller area (PC) LMPS (Figs. S2B-G) and compare the resultant undecompacted net sediment accumulation rates with other eastern Ebro chronostratigraphies (Fig. 9). Although these alternative interpretations offer resolutions to problems that arise through comparative analysis of the RMSB \& PC LMPS (Fig. 3), each interpretation is compromised by one or more lines of incompatible 

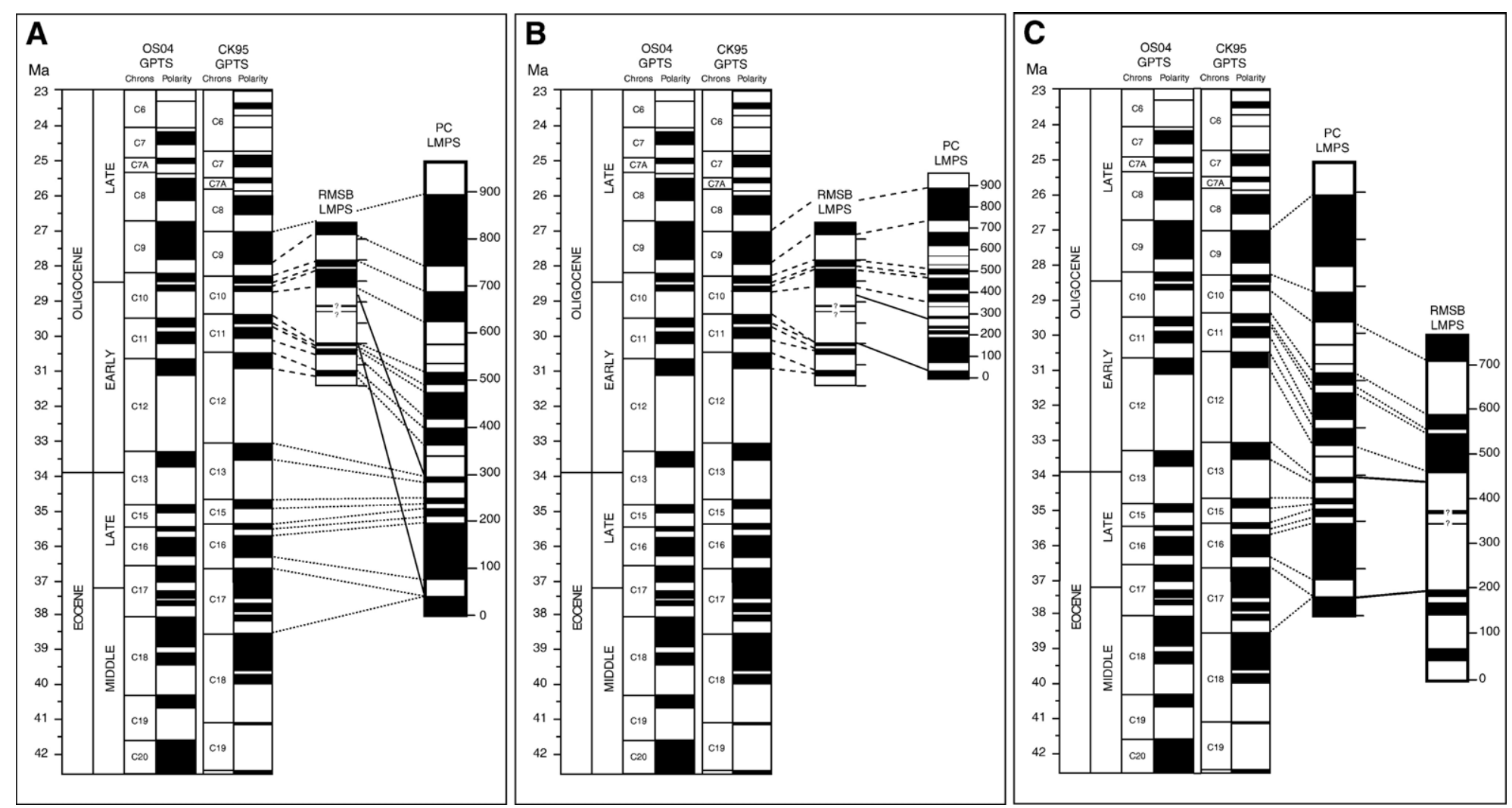

Fig. 8. Comparison of Rodamunts-Muntanya de Santa Bàrbara (RMSB, this study) and Puig Cavaller area (PC, (Jones et al., 2004) LMPS to the CK95 and OS04 GPTS. A: This study's preferred correlation of the RMSB LMPS to the GPTS alongside Jones et al.'s correlation of the PC LMPS. B: Forcing of the PC LMPS to this study's preferred correlation of the RMSB LMPS along lithostratigraphic markers (solid lines) yields logical and steady sedimentation rates but requires rejection of three normal polarity zones in the PC LMPS not present in the RMSB LMPS nor the GPTS. C: Forcing of the RMSB LMPS to Jones et al.'s preferred correlation of the PC LMPS yields steady but slow sedimentation rates and requires rejection of three normal polarity zones in the PC LMPS and that correspond to three normal polarity chrons of the GPTS but are not recorded in the RMSB LMPS. 
evidence: (1) rejection of GPTS or LMPS polarity zones, (2) unsteady sedimentation rates that are not indicated by the stratigraphic architecture, or (3) sedimentation rates that are incompatible with better constrained chronostratigraphies of related and comparable deposystems.

When the RMSB LMPS is forced to match Jones et al.'s (2004) interpretation of the PC LMPS and honors the lithostratigraphic correlation presented in Fig. 3 (interpretation RMSB-B in Figs. S1B and C), relatively steady sedimentation rates are achieved but the section overlaps with three normal polarity chrons (C15n, C16n.1n, C16n.2n) in the GPTS that are not recognized in the RMSB LMPS. Moreover, this interpretation requires unreasonably slow alluvial-fan sedimentation rates $(\sim 6 \mathrm{~cm} / \mathrm{ka})$ based on comparison to the rates $(\sim 16 \mathrm{~cm} / \mathrm{ka})$ well constrained from equivalent but more distal fluvial facies (Barberà et al., 2001).

Forcing the RMSB LMPS to match Jones et al.'s (2004) interpretation of the PC LMPS without honoring the lithostratigraphic correlation presented in Fig. 3 (interpretation RMSB-E in Fig. S1E) does not require rejection of significant polarity zones in the LMPS or chrons of the GPTS and yields steady sedimentation rates, but these rates are excessively slow ( $\sim 8 \mathrm{~cm} / \mathrm{ka}$ ) for alluvial-fan deposystems in comparison to coeval distal fluvial and lacustrine sedimentation rates (Barberà et al., 2001).

When the PC LMPS is forced to our preferred interpretation of the RMSB LMPS (interpretations PC-D and PC-E in Figs. 8C, 9, S2D and E), relatively steady sedimentation rates are achieved, but the correlation requires rejection of four normal polarity zones that occur in the PC LMPS but not in the GPTS (between chrons C10n.2n and C11n.1n), nor the RMSB LMPS. Resultant undecompacted net sediment accumulation rates $(\sim 20-36 \mathrm{~cm} / \mathrm{ka})$ are logical with respect to rates that are well constrained from more distal facies (Fig. 9, Barberà et al., 2001).

We also examine four alternative interpretations of the PC LMPS (interpretations PC-B, PC-C, PC-F, and PC-G in Figs. S2 and 9) designed to adjust the projected E. zitteli local biozone to its proper location at the top of the $\mathrm{C} 10 \mathrm{n}$. $1 \mathrm{n}$ chron instead of the correlation to the top of the $\mathrm{C} 9 \mathrm{n}$ chron that Jones et al. (2004) employed. Each of these interpretations requires unsteady sedimentation rates that are not indicated by the stratigraphic architecture. Moreover, all but one of the alternative correlations (PC$\mathrm{G} ; \sim 14 \mathrm{~cm} / \mathrm{ka}$ ) results in average sedimentation rates that are much slower $(\sim 6 \mathrm{~cm} / \mathrm{ka})$ than those of Barberà et al.'s (2001) distal fluvial facies. Likewise, when the RMSB LMPS is forced to fit the adjusted PC LMPS and honors the lithostratigraphic correlation presented in Figs. 2 and 3 (interpretations RMSB-C and RMSB-D in Fig. 9, S1C and
D), it yields unsteady and slow sedimentation rates $(\sim 8 \mathrm{~cm} /$ ka). Given the above considerations and the difficulty projecting from the E. zitteli fossil site near Gandesa to the Puig Cavaller region (Jones et al., 2004), these alternative correlations should not be accepted with high confidence.

In light of these alternative interpretations of the RMSB and PC LMPS, we raise three concerns about the existing age interpretation of the Puig Cavaller area magnetostratigraphy (Jones et al., 2004) that together encourage consideration of the new age interpretations for the southern Ebro syntectonic succession presented herein.

(1) The $\sim 1000 \mathrm{~m}$ magnetostratigraphic section reported in Jones et al. was collected along a $9 \mathrm{~km}$ horizontal transect oriented obliquely to the structural and depositional front of the CCR (Fig. 2). This sampling transect crossed (a) an important facies boundary that separates alluvial-fan strata derived from the immediately adjacent CCR from fluvial strata of the Guadalope-Matarranya fluvial system derived from the Linking Zone, $\sim 50 \mathrm{~km}$ to the south (Anadón et al., 1989; Jones, 1997; Jones et al., 2004), and (b) an inferred structural boundary marked by the southwest termination of the Fontcalda anticline (Fig. 2). The new data presented herein were collected wholly from continuously exposed strata that are most proximal to the modern CCR, covering a region in which any two samples are no more than $3 \mathrm{~km}$ apart (Fig. 2 and Fig. 3). This approach has allowed us to minimize potential complications introduced by intercalations of the Guadalope-Matarranya fluvial system and projection across poorly exposed intervals.

(2) Jones et al.'s miscorrelation of the E. zitteli local biozone locality near Gandesa (Barberà et al., 2001) to chron C9n instead of chron C10n.1n either underscores the difficulty of projecting folded alluvial-fan strata across poorly exposed intervals, or yields corrected GPTS interpretations that are tenuous due to the resultant unsteady and slow net sediment accumulation history (Figs. 8, 9, S2) that is contradicted by chronostratigraphic analysis of similar strata (Burbank et al., 1996; Garcés et al., 2002).

(3) The sedimentation rates that result from our preferred correlation of the RMSB LMPS to the Paleogene GPTS (Fig. 9) are steady and logical with respect to sedimentation rates reported from associated (Barberà et al., 2001) and similar (Sadler, 1981; Burbank et al., 1996; LopezBlanco et al., 2000; Garcés et al., 2002) strata. Whereas the resultant sedimentation rates of the 


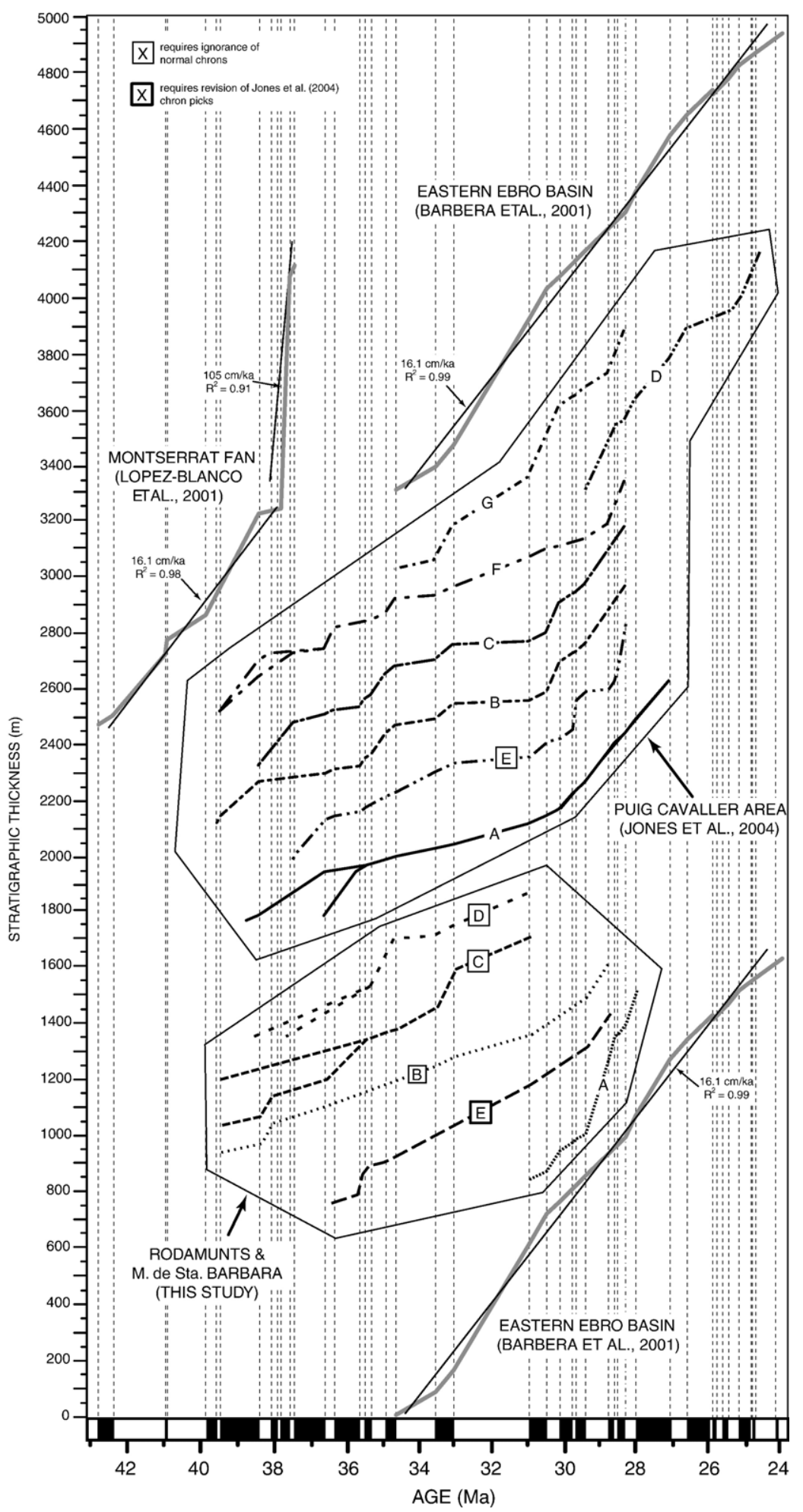

Fig. 9. Comparison of undecompacted net sediment accumulation rates of RMSB and PC LMPS interpretations presented herein and from Jones et al. (2004) with the integrated fluvio-lacustrine magnetobiostratigraphy of Barberà et al. (2001) and alluvial-fan magnetostratigraphy of Lopez-Blanco et al. (2000). See Figs. 5, 8, S1 and S2 for LMPS-GPTS correlations and Table S1 and text for discussion. 
Jones et al. LMPS interpretation are steady, they yield a thick interval of alluvial-fan strata with net sediment accumulation rates that are nearly $50 \%$ slower than better-constrained rates of coeval lacustrine and distal fluvial strata in the medial part of the basin (Fig. 5 and Fig. 9; Barberà et al., 2001). If true, this spatial distribution of sedimentation rates would have caused a retrogradation of the alluvial-fan succession and an attendant orogen-ward migration of distal basin facies for which there is no evidence in the stratigraphic architecture of the study area.

Despite the improvements offered by our preferred correlation of the RMSB LMPS to the Paleogene GPTS, the new magnetostratigraphy suffers from a lack of proximity to fossil localities that could more securely tie the LMPS to the GPTS and the absolute geologic timescale. Whereas proximity to fossil localities might improve the robustness of GPTS correlations, we note that discrepancies between the reported (Barberà et al., 2001) and utilized (Jones et al., 2004) ages and chrons of existing fossil localities emphasize the low confidence of correlation between distal facies (where such localities are common) and their energetic, fossil-poor proximal counterparts. A more detailed magnetostratigraphic sampling routine may better constrain the absolute age and stratigraphic completeness of the study interval.

\subsection{Implications for alluvial fan deposystems and proxy data}

Regardless of the true absolute ages of the RodamuntsMuntanya de Santa Bàrbara and Puig Cavaller region strata examined herein and in Jones (1997) and Jones et al. (2004), this study suggests that lithostratigraphically correlative strata in alluvial-fan deposits of proximal foreland basin depozones have chronostratigraphic significance over short distances, but not over long distances $(>\sim 5 \mathrm{~km})$. Whereas detailed study of marginal-marine strata tests the sequence stratigraphic interpretive framework (Van Wagoner et al., 1988), terrestrial proximal foreland basin depozones distribute and accumulate sediment in ways that are fundamentally different from shallow-marine settings (Shanley and McCabe, 1994; Currie, 1997). In particular, autocyclic and avulsive processes inherent to proximal, fan-shaped deposystems generate a spatially complicated distribution of chronostratigraphically significant surfaces that inhibit application of traditional sequence stratigraphic frameworks.

Schumm et al. (1987) presented results from an experimental physical model of alluvial-fan dynamics that depicts entrenchment-backfill-dispersion cyclicity and suggests that some components of alluvial-fan lithostratigraphy should have chronostratigraphic significance. In particular, dispersal phases distribute thin, but laterally continuous, fine-grained sediments over large areas of alluvial fans. The presence of widespread fine-grained intervals in ancient alluvial-fan strata (DeCelles et al., 1991a; Weissmann et al., 2002), including the study area (Barbeau, 2003), suggests that this can be tested through along-strike lithostratigraphic correlations of magnetostratigraphic sections (Fig. 2 and Fig. 3), as the fine-grained lithostratigraphic markers should connect intervals with the same magnetic polarity.

Our new data demonstrate an apparent contradiction of this assumption (Figs. 2, 3, 8) and suggest that chronostratigraphic models for alluvial-fan sediment accumulation need to be reconsidered. Whereas the fine-grained intervals used for lithostratigraphic correlation in the study area appear to have chronostratigraphic significance over short distances $(<2 \mathrm{~km})$ as indicated by the overlaps in the SB, CG, RDM and S5 LMPS, conflicts between the intervals of the RMSB LMPS and PC LMPS that are connected by continuously exposed, lithostratigraphically equivalent strata suggest that chronostratigraphic and lithostratigraphic surfaces vary over longer distances (Fig. 2, Fig. 3, and Fig. 8). In addition to magnetostratigraphic studies that compile composite LMPS from multiple individual sections, any proxy data collection that uses a similar technique of lateral correlation may be collecting incomplete or duplicated serial data.

\subsection{Iberian plate tectonics}

Robust evidence of growth strata in the RMSB section occurs $480 \mathrm{~m}$ into the composite LMPS (Barbeau, 2003). Based on our preferred correlation of the LMPS to the CK95 GPTS, this growth began at ca. $28.5 \mathrm{Ma}$ and indicates the arrival of the orogenic wedge. If our new magnetostratigraphic interpretations are correct, the southwestern CCR orogenic wedge was active from 28.5 Ma to at least 27.6 Ma (late Oligocene). The increase in net sediment accumulation rate and the transition to an alluvial-fan system 180-200 m into the LMPS is indicative of proximity to a high-relief source region-requiring that CCR shortening was in progress no later than ca. 29.6 Ma.

This timing of local deformation in the CCR is compatible with Schettino and Turco's (2006) model for western Mediterranean Oligocene plate kinematics that attributes folding and faulting in the CCR to a stress regime that developed after the cessation of the Pyrenean orogeny as the convergent boundary between Africa and 
Eurasia jumped southward. Uplift in the CCR thrust belt likely began earlier than 29.6 Ma, however, as enough topography was present after the Middle-Late Eocene boundary $(\sim 37 \mathrm{Ma})$ to maintain the Ebro basin as an intermontane basin dominated by terrestrial sedimentation (Vergés et al., 2002). This timing could then fit with models that explain the CCR as a manifestation of intraplate stresses resulting from the late stages of the Pyrenean orogeny.

\section{Conclusions}

1. Paleomagnetic analysis of $\sim 865 \mathrm{~m}$ of alluvial-fan strata in the southeastern Ebro Basin reveals 15 reversals within a $\sim 760 \mathrm{~m}$ composite succession. Correlation of the resulting local magnetic polarity stratigraphy to the Paleogene global polarity time scale of Cande and Kent (1995) dates deposition from 31.4 to $27.7 \mathrm{Ma}$ (C12r-C9n; early to late Oligocene). This correlation requires an increase in sedimentation rates from $\sim 12 \mathrm{~cm} / \mathrm{ka}$ to $\sim 32 \mathrm{~cm} / \mathrm{ka}$ at ca. $29.6 \mathrm{Ma}$ (base of C11n.1), which is coincident with the transition from fluvial to alluvial-fan sedimentation.

2. The above interpretation is in apparent conflict with the interpretation of previous magnetostratigraphic analyses of broadly equivalent strata attributed to the stratigraphy of Puig Cavaller, $<10 \mathrm{~km}$ to the north and northeast of the study area (Jones, 1997; Jones et al., 2004). Attempts to force the Rodamunts-Muntanya de Santa Bàrbara LMPS to match the Puig Cavaller area LMPS (and vice versa) require unsteady sedimentation rates that are not supported by the stratigraphic and pedogenic architecture of the studied interval (Jones et al., 2004; Barbeau, 2003). Whereas this discrepancy could be partially attributed to tenuous lithostratigraphic and biostratigraphic correlations and assumptions utilized in construction of previous workers' composite LMPS, lithostratigraphic correlation of the only continuously exposed interval common to the two studied composite sections reveals disparate magnetic polarity zonations. The occurrence of a significant structural boundary between the study areas further suggests that these strata may be diachronous. In light of these considerations, we suggest that the magnetostratigraphic interpretation proposed herein be used for the previously undated wedge-top and proximal foredeep strata preserved southwest of the down-plunge termination of the Fontcalda anticline in the vicinity of Rodamunts and Muntanya de Santa Bàrbara until a more accurate chronostratigraphy can be acquired.

3. The above-mentioned discrepancies between magnetic polarity zonations of lithostratigraphically correlatable alluvial-fan strata in the studied interval suggest that the dynamics of fan-shaped avulsive deposystems (i.e., alluvial fans, deltas, submarine fans) may preclude the use of lithostratigraphic markers for moderate and long distance (greater than $\sim 5 \mathrm{~km}$ in the present study) chronostratigraphic correlation in such settings. As a result, tectonosedimentary and sediment-distribution models supported by data using such lithostratigraphic correlations may need to be reconsidered until more robust data can be acquired. Moreover, geoscientists who collect proxy data from composite stratigraphic sections in alluvial-fan strata should be wary of the apparent diachroneity of lithostratigraphy in such settings. Sampling strategies employed in alluvial-fan strata should include large percentages of vertical overlap and minimization of lateral and down-dip lithostratigraphic correlation distances.

4. Using this study's preferred correlation of the RMSB LMPS to the GPTS, onset of synkinematic deposition in the RMSB region as reflected by growth strata occurred at ca. 28.5 Ma with wedge-top deposition continuing until at least 27.7 Ma. If accurate, models of western Mediterranean kinematics should be consistent with arrival of the southernmost Catalan Coastal Range orogenic wedge in southern Catalunya in the late Early Oligocene. However, upon evaluation of the possible correlation complexities of the PC LMPS and the apparent diachroneity between the overlapping RMSB and PC sections, this age may be older.

\section{Acknowledgments}

This work was supported by the Duncan Stewart Fellowship (Carleton College) awarded to NSH and support provided to DLB through ExxonMobil Upstream Research Company and the University of South Carolina. Joe Kirschvink generously provided access to his paleomagnetism laboratory at Caltech. Dave Bice was instrumental in the development of this project. Amy Moragues, Kate Stalker and Ellen Schaal provided assistance in the field. Bob Butler, Tim Lawton, Miguel Garcés, Adam Maloof, Cam Davidson and Ross Mitchell reviewed previous versions of the manuscript. Bob Kopp, Bereket Haileab, Clint Cowan and Chris Povaola assisted with laboratory analysis and data interpretation. La Familia Miralles provided generous support and hospitality.

\section{Appendix A. Supplementary data}

Supplementary data associated with this article can be found, in the online version, at doi:10.1016/j. eps1.2007.07.003. 


\section{References}

Agustí, J., Cabrera, L., Anadón, P., Arbiol, S., 1988. A Late Oligocene/ Early Miocene rodent biozonation from the SE Ebro Basin (NE Spain): a potential mammal stage stratotype. Newsletters on Stratigraphy 18, 81-97.

Anadón, P., Cabrera, L., Guimerà, J., Santanach, P., 1985. Paleogene strike-slip deformation and sedimentation along the southeastern margin of the Ebro Basin. In: Biddle, K.T., Christie-Blick, N. (Eds.), Strike-slip Deformation, Basin Formation and Sedimentation. Special Publication of the Society of Economic Paleontologists and Mineralogists, vol. 37, pp. 303-318.

Anadón, P., Cabrera, L., Colombo, F., Marzo, M., Riba, O., 1986. Syntectonic intraformational unconformities in alluvial fan deposits eastern Ebro Basin margins (NE Spain). Special Publication of the International Association of Sedimentologists, vol. 8, pp. 259-271.

Anadón, P., Cabrera, L., Colldeforms, B., Colombo, F., Cuevas, J.L., Marzo, M., 1989. Alluvial fan evolution in the S.E. Ebro basin: response to tectonics and lacustrine base-level changes, Excursion Guidebook No. 9, 4th International Conference on Fluvial Sedimentology, Publ. Serv. Geol. Cat., 91pp.

Anadón, P., Cabrera, Ll., Choi, S.J., Colombo, F., Feist, M., Sáez, A., 1992. Biozonación del Paleógeno continental de la zona oriental de la Cuenca del Ebro mediante carófitas: implicaciónes en la biozonación general de carófitas de Europa occidental. Acta Geologica Hispanica 27, 29-40.

Arenas, C., Millán, H., Pardo, G., Pocoví, A., 2001. Ebro Basin continental sedimentation associated with late compressional Pyrenean tectonics (north-eastern Iberia): controls on basin margin fans and fluvial systems. Basin Research 13, 65-89.

Barbeau, D.L., 2003. Application of growth strata and detrital-zircon geochronology to facies architecture and kinematic histories, (Ph.D. Dissertation), University of Arizona, 227pp.

Barberà, X., Parés, J.M., Cabrera, L., Anadón, P., 1994. High-resolution magnetic stratigraphy across the Oligocene-Miocene boundary in an alluvial-lacustrine succession (Ebro Basin, Northeast Spain). Physics of the Earth and Planetary Interiors 85, 181-193.

Barberà, X., Cabrera, L., Marzo, M., Parés, J.M., Agustí, J., 2001. A complete terrestrial Oligocene magnetobiostratigraphy from the Ebro Basin, Spain. Earth and Planetary Science Letters 187, 1-16.

Behrensmeyer, A.K., Tauxe, L., 1982. Isochronous fluvial systems in Miocene deposits of northern Pakistan. Sedimentology 29, 331-352.

Blair, T.C., Bilodeau, W.L., 1988. Development of tectonic cyclothems in rift, pull-apart, and foreland basins: sedimentary response to episodic tectonism. Geology 16, 517-520.

Bohacs, K.M., Carroll, A.R., Neal, J.E., Mankiewicz, P.J., 2000. Lakebasin type, source potential, and hydrocarbon character: an integrated sequence-stratigraphic geochemical framework: American Association of Petroleum Geologists Memoir. In: GierlowskiKordesch, E.H., Kelts, K. (Eds.), Lake Basins Through Space and Time: AAPG Studies in Geology, vol. 46, pp. 3-33.

Bourquin, S., Rigollet, C., Bourges, P., 1998. High-resolution sequence stratigraphy of an alluvial fan-fan delta environment: stratigraphic and geodynamic implications - an example from the Keuper Chaunoy Sandstones, Paris Basin. Sedimentary Geology 121, 207-237.

Brozovíc, N., Burbank, D.W., 2000. Dynamic fluvial systems and gravel progradation in the Himalayan foreland. Geological Society of America Bulletin 112, 394-412.

Burbank, D.W., Puigdefäbregas, C., Muñoz, J.A., 1992. The chronology of the Eocene tectonic and stratigraphic development of the eastern Pyrenean foreland basin, northeast Spain. Geological Society of America Bulletin 104, 1101-1120.

Burbank, D.W., Meigs, A., Brozovíc, N., 1996. Interactions of growing folds and coeval deposystems. Basin Research 8, 199-223.

Butler, R.F., Ojha, T.P., Quade, J., DeCelles, P.G., 2001. Magnetic polarity stratigraphy of Siwalik Group sediments in Nepal: diachronous lithostratigraphy and isochronous carbon isotope shift. Eos, Trans AGU 82.

Cabrera, Ll., Colombo, F., Robles, S., 1985. Sedimentation and tectonics interrelationships in the Paleogene marginal alluvial system of the SE Ebro basin, transition from alluvial to shallow lacustrine environments. In: Mila, M., Rosell, J. (Eds.), Excursion Guide Book of the Sixth European Regional IAS Meeting. Excursion, vol. 10, pp. 393-492.

Cande, S.C., Kent, D.V., 1995. Revised calibration of the geomagnetic polarity timescale for the Late Cretaceous and Cenozoic. Journal of Geophysical Research 100, 6093-6095.

Colombo, F., 1994. Normal and reverse unroofing sequences in syntectonic conglomerates as evidence of progressive basinward deformation. Geology 22, 235-238.

Currie, B.S., 1997. Sequence stratigraphy of nonmarine JurassicCretaceous rocks, central Cordilleran foreland-basin system. Geological Society of America Bulletin 109, 1206-1222.

DeCelles, P.G., Mitra, G., 1995. History of the Sevier orogenic wedge in terms of critical taper model, Northeast Utah and Southwest Wyoming. Geological Society of America Bulletin 107, 454-462.

DeCelles, P.G., Gray, M.B., Ridgway, K.D., Cole, R.B., Srivastava, P., Pequera, N., Pivnik, D.A., 1991a. Kinematic history of a foreland uplift from Paleocene synorogenic conglomerate, Beartooth Range, Wyoming and Montana. Geological Society of America Bulletin 103, 1458-1475.

DeCelles, P.G., Gray, M.B., Ridgway, K.D., Cole, R.B., Pivnik, D.A., Pequera, N., Srivastava, P., 1991b. Controls on synorogenic alluvial-fan architecture, Beartooth Conglomerate (Palaeocene), Wyoming and Montana. Sedimentology 38, 567-590.

Dickinson, W.R., 2003. The place and power of myth in geoscience: an associate editor's perspective. American Journal of Science 303, $856-864$.

Fitzgerald, P.G., Muñoz, J.A., Coney, P.J., Baldwin, S.L., 1999. Asymmetric exhumation across the Pyrenean orogen; implications for the tectonic evolution of a collisional orogen. Earth and Planetary Science Letters 173, 157-170.

Fraser, G.S., DeCelles, P.G., 1992. Geomorphic controls on sediment accumulation at margins of foreland basins. Basin Research 4, $233-252$.

Gani, M.R., Bhattacharya, J.P., 2005. Bedding correlation vs facies correlation in deltas: Lessons for Quaternary stratigraphy. In: Giosan, L., Bhattacharya, J.P. (Eds.), River Deltas: Concepts, Models and Examples, vol. 83. SEPM Special Publication, pp. 31-48.

Garcés, M., Beamud, E., Muñoz, J.A., Cabrera, L., 2002. Magnetostratigraphic correlation and completeness of the stratigraphic record in continental alluvial sediments: examples from the southPyrenean foreland basin. Geophysical Research Abstracts, 1.

García-Castellanos, D., Vergés, J., Gaspar-Escribano, J., Cloetingh, S., 2003. Interplay between tectonics, climate, and fluvial transport during the Cenozoic evolution of the Ebro Basin (NE Iberia). Journal of Geophysical Research 108, 2347.

Gaspar-Escribano, J.M., García-Castellanos, D., Roca, E., Cloetingh, S., 2004. Cenozoic vertical motions of the Catalan Coastal Ranges (NE Spain): the role of tectonics, isostasy and surface transport. Tectonics 23, 1004 (TC), doi:10.1029/2003TC001511.

Guimerà, J., 1984. Paleogene evolution of deformation in the northeastern Iberian peninsula. Geological Magazine 121, 413-420. 
Heller, P.L., Angevine, C.L., Winslow, N.S., Paola, C., 1988. Twophase stratigraphic model of foreland-basin sequences. Geology $16,501-504$.

Hogan, P.J., Burbank, D., 1996. Evolution of the Jaca piggyback basin and emergence of the External Sierra, southern Pyrenees. In: Friend, P.F., Dabrio, J.C. (Eds.), Tertiary Basins of Spain: The Stratigraphic Record of Crustal Kinematics. Cambridge University Press, pp. 153-160.

Jones, M.A., 1997. Interaction between proximal foreland basin sedimentation and the structural evolution of the Catalan Coastal Range, near Gandesa, Catalunya, (Ph.D. Dissertation), University of Wyoming, $237 \mathrm{pp}$.

Jones, M.A., Heller, P.L., Roca, E., Garcés, M., Cabrera, L., 2004. Time lag of syntectonic sedimentation across an alluvial basin: theory and example from the Ebro Basin, Spain. Basin Research $16,467-488$.

Keighley, D., Flint, S., Howell, J., Moscariello, A., 2003. Sequence stratigraphy in lacustrine basins: a model for part of the Green River Formation (Eocene), southwest Uinta Basin, Utah. Journal of Sedimentary Research 73, 987-1006.

Kirschvink, J.L., 1980. The least-squares line and plane and the analysis of palaeomagnetic data. Geophysical Journal of the Royal Astronomical Society 62, 699-718.

Lawton, T., Roca, E., Guimerà, J., 1999. Kinematic-stratigraphic evolution of a growth syncline and its implications for tectonic development of the proximal foreland basin, southeastern Ebro basin, Catalunya, Spain. Geological Society of America Bulletin $111,412-431$.

Lonergan, L., White, N., 1997. Origin of the Betic-Rif mountain belt. Tectonics 16, 504-522.

López, F., García, A., Barnolas, A., Simó, A., González, J., Calvet, F., Granados, L., 1985. Horta de San Juan: Instituto Geológico y Minero de España. Mapa Geológico de España 496 (scale: 1:50000) 47 pp.

Lopez-Blanco, M., 2002. Sedimentary response to thrusting and fold growing on the SE margin of the Ebro Basin (Paleogene, NE Spain). Sedimentary Geology 146, 133-154.

Lopez-Blanco, M., Marzo, M., Burbank, D.W., Verges, J., Roca, E., Anadón, P., Pina, J., 2000. Tectonic and climatic controls on the development of foreland fan deltas: Montserrat and Sant Llorenç del Munt systems (Middle Eocene, Ebro Basin, NE Spain). Sedimentary Geology 138, 17-39.

McElhinny, M.W., 1964. Statistical significance of the fold test in Paleomagnetism. Journal of the Royal Astronomical Society 7, 457-468.

Meigs, A.J., Vergés, J., Burbank, D.W., 1996. Ten-million-year history of a thrust sheet. Geological Society of America Bulletin 108, 1608-1625.

Miall, A.D., Miall, C.E., 2000. Sequence stratigraphy as a scientific enterprise: the evolution and persistence of conflicting paradigms. Earth Science Reviews 54, 321-348.

Monié, P., Galindo-Zaldivar, J., Gonzalez Lodeiro, F., Goffé, B., Jabaloy, A., 1991. ${ }^{40} \mathrm{Ar} /{ }^{39} \mathrm{Ar}$ geochronology of Alpine tectonism in the Betic Cordilleras (southern Spain). Journal of the Geological Society $148,289-297$.

Muñoz, J.A., 1992. Evolution of a continental collision belt; ECORSPyrenees crustal balanced cross-section. In: McClay, K.R. (Ed.), Thrust tectonics. Chapman and Hall, pp. 235-246.

Nichols, D.J., 2002. Correlation of Palynostratigraphy and magnetostratigraphy in Maastrichtian-Eocene Strata in the Denver Basin, Colorado, GSA Abstracts with Programs, 34, p. 508.

Ogg, J.G., Smith, A.G., 2004. The geomagnetic polarity time scale. In: Gradstein, F.M., Ogg, J.G., Smith, A.G. (Eds.), A Geologic Time Scale 2004. Cambridge University Press, pp. 63-86.
Oms, O., Dinarés-Turell, J., Remacha, E., 2003. Magnetic stratigraphy from deep clastic turbidites: an example from the Eocene Hecho Group (southern Pyrenees). Studia Geophysica et Geodaetica 47, 275-288.

Prothero, D.R., 2001. Magnetostratigraphic tests of sequence stratigraphic correlations from the southern California Paleogene. Journal of Sedimentary Research 71, 525-535.

Roca, E., Sans, M., Cabrera, L., Marzo, M., 1999. Oligocene to Middle Miocene evolution of the central Catalan margin (northwestern Mediterranean. Tectonophysics 315, 209-233.

Roest, W.R., Srivastava, S.P., 1991. Kinematics of the plate boundaries between Eurasia, Iberia, and Africa in the North Atlantic from the Late Cretaceous to the present. Geology 19, 613-616.

Rosenbaum, G., Lister, G.S., Duboz, C., 2002. Relative Motions of Africa, Iberia and Europe during Alpine Orogeny. Tectonophysics $359,117-129$.

Rosenbaum, G., Regenauer-Lieb, K., Weinberg, R., 2005. Continental extension: from core complexes to rigid block faulting. Geology 33, 609-612.

Rosseti, F., Faccenna, C., Jolivet, L., Funiciello, R., Tecce, F., Brunet, C., 1999. Syn-versus post-orogenic extension: the case study of Giglio Island (Northern Tyrrhenian Sea, Italy). Tectonophysics 304, 71-93.

Sadler, P.M., 1981. Sediment accumulation rates and the completeness of stratigraphic sections. Journal of Geology 89, 569-584.

Schettino, A., Scotese, C., 2002. Global kinematic constraints to the tectonic history of the Mediterranean region and surrounding areas during the Jurassic and Cretaceous. Journal of the Virtual Explorer 8, 149-168.

Schettino, A., Turco, E., 2006. Plate kinematics of the Western Mediterranean region during the Oligocene and Early Miocene. Geophysical Journal International 166, 1398-1423.

Schumm, S.A., Mosley, M.P., Weaver, W.E., 1987. Experimental Fluvial Geomorphology. John Wiley \& Sons. (413 pp.).

Shanley, K.W., McCabe, P.J., 1994. Perspectives on the sequence stratigraphy of continental strata. AAPG Bulletin 78, 544-568.

Srivastava, S.P., Schouten, H., Roest, W.R., Klitgord, K.D., Kovacs, L. C., Verhoef, J., Macnab, R.F., 1990. Iberian Plate kinematics: a jumping plate boundary between Eurasia and Africa. Nature 344, 756-759.

Turner, P., Hirst, J.P.P., Friend, P.F., 1984. A palaeomagnetic analysis of Miocene fluvial sediments at Pertusa, near Huesca, Ebro Basin, Spain. Geological Magazine 121, 279-290.

Vail, P.R., Mitchum Jr., R.M., Thompson III, S., Todd, R.G., Sangree, J.B., Widmier, J.M., Bubb, J.N., Hatelid, W.G., 1977. Seismic stratigraphy and global sea level changes. In: Payton, C.E. (Ed.), Stratigraphic Interpretation of Seismic Data. AAPG Memoir 26, pp. 49-212.

Van Wagoner, J.C., Posamentier, H.W., Mitchum Jr., R.M., Vail, P.R., Sarg, J.F., Loutit, T.S., Hardenbol, J., 1988. An overview of the fundamentals of sequence stratigraphy and key definitions. In: Wilgus, C.K., Hastings, B.S., Ross, C.A., Posamentier, H.A., Van Wagoner, J., Kendall, C.St.C.G. (Eds.), Sea-level Changes; An Integrated Approach. Special Publication of the Society of Economic Paleontologists and Mineralogists, pp. 39-45.

Vergés, J., Fernandez, M., Martinez, A., 2002. The Pyrenean orogen: pre-, syn-, and post-collisional evolution. Journal of the Virtual Explorer 8, 57-76.

Weissmann, G.S., Mount, J.F., Fogg, G.E., 2002. Glacially driven cycles in accumulation space and sequence stratigraphy of a streamdominated alluvial fan, San Joaquin Valley, California, U.S.A. Journal of Sedimentary Research 72, 240-251. 
Woodburne, M.O., 1987. Cenozoic Mammals of North America: Geochronology and Biostratigraphy. University of California Press. 336 pp.

Wortmann, U.G., Weissert, H., Funk, H., Hauck, J., 2001. Alpine plate kinematics revisited: the Adria problem. Tectonics 20, 134-147.

Zechun, L., Yongjin, W., Ye, C., Xuesong, L., Qingchen, L., 1998. Magnetostratigraphy and sedimentologically derived geochronology of the Quaternary lacustrine deposits of a $3000 \mathrm{~m}$ thick sequence in the central Qaidam basin, western China. Palaeogeography, Palaeoclimatology, Palaeocology 140, 459-473.
Zijderveld, J.D.A., 1967. Demagnetization of rocks: analysis of results. In: Collinson, D.W., Creer, K.M., Runcorn, S.K. (Eds.), Methods in Paleomagnetism. Elsevier, pp. 254-286.

Zoetemeijer, R., Desegaulx, P., Cloetingh, S.A.P.L., Roure, F., Moretti, I., 1990. Lithospheric dynamics and tectonic-stratigraphic evolution of the Ebro Basin: Journal of Geophysical Research 95, $2701-2711$. 
Discussion

\title{
Reply to Garcés et al. comment on 'The diachroneity of alluvial-fan lithostratigraphy? A test case from southeastern Ebro Basin magnetostratigraphy'
}

\author{
Nicholas Swanson-Hysell a,1, David L. Barbeau, Jr. b,* \\ a Department of Geosciences, Princeton University, Washington Rd., Princeton, NJ 08544, USA \\ b Department of Geological Sciences, University of South Carolina, Columbia, SC 29208, USA
}

\section{A R T I C L E I N F O}

Article history:

Accepted 15 July 2008

Available online 22 July 2008

Editor R.W. Carlson

\section{Introduction}

We thank M. Garcés, L. Cabrera, E. Roca and O. Gratacós for engaging us in this discussion and for providing us with the opportunity to further examine the challenges and pitfalls of developing rigorous chronostratigraphic models in proximal foreland basin strata. We appreciate their favorable assessment of our field and laboratory methods and their acknowledgment that our new data contribute to the chronostratigraphy of the study area. As demonstrated by our conflicting interpretations of the Rodamunts and Muntanya de Santa Bàrbara (RMSB) local magnetic polarity stratigraphy (Swanson-Hysell and Barbeau, 2007; Garcés et al., 2008-this issue), the dating of these and other coarse-grained syntectonic successions remains an obstacle to geoscientists, and is deserving of further attention. We are hopeful that this discussion will ultimately lead to a more robustly supported and accurate age model for the Paleogene stratigraphy of the southeastern Ebro Basin than currently exists. Most importantly, this discourse has the potential to improve the approaches used by the larger scientific community in the collection, interpretation, and application of a wide range of stratigraphic data, including, but not limited to, local magnetic polarity stratigraphies.

The stratigraphic record preserves myriad data that are applicable to a range of important Earth phenomena, but without accurate and precise age models such data are of limited use (e.g., Westerhold and Röhl, 2008). In our view, an accurate stratigraphic age model must be reproducible and internally consistent; hence the examination of single or apparently equivalent successions by multiple laboratories or efforts is essential (e.g., Heizler and EARTHTIME Ar working group,

DOI's of original article: 10.1016/j.epsl.2007.07.003, 10.1016/j.epsl.2008.07.024.

* Corresponding author. Tel.: +1 8037775162.

E-mail addresses: nswanson@princeton.edu (N. Swanson-Hysell), dbarbeau@geol.sc.edu (D.L. Barbeau).

1 Tel.: +1 6092580836 .
2008). Disparities in the resulting data cannot be disregarded on the basis of conjecture. Because of the potentially ambiguous nature of magnetostratigraphic correlations to the geomagnetic polarity timescale (GPTS), reproducible results from a diversity of "equivalent" sections are especially crucial in stratigraphic successions that lack radiometric or sufficient biostratigraphic age control within the immediate section.

In this contribution, we:

(1) address changes in the observations made in our original contribution in light of newly presented, essential metadata related to the Bot local magnetic polarity stratigraphy (LMPS) that has been reported for the first time in this volume (Figs. 1 and S2 of Garcés et al., 2008-this issue, and our Fig. 1) and that differs slightly but significantly from previously available material.

(2) respond to criticism regarding our discussion of the interplay between tectonics and sedimentation in the studied stratigraphy and point out inconsistencies between the implied sedimentation rates of the Garcés et al. (2008)-this issue age model and the valid hypothesis that sedimentation rates could be reduced in a wedge-top setting.

(3) detail our significant, well-founded doubts about the methods and assumptions that were used to construct the composite LMPS utilized by Jones et al. (2004) and presented again by Garcés et al. (2008)-this issue.

(4) identify which magnetostratigraphic sections from the larger study area we consider sufficiently robust data to apply to understanding the chronostratigraphy of the Montsant Formation.

\section{LMPS comparison methods and magnetostratigraphic metadata}

To begin, we address Garcés et al.'s criticism of our comparative methods so that we may explain the circumstances and justification for 


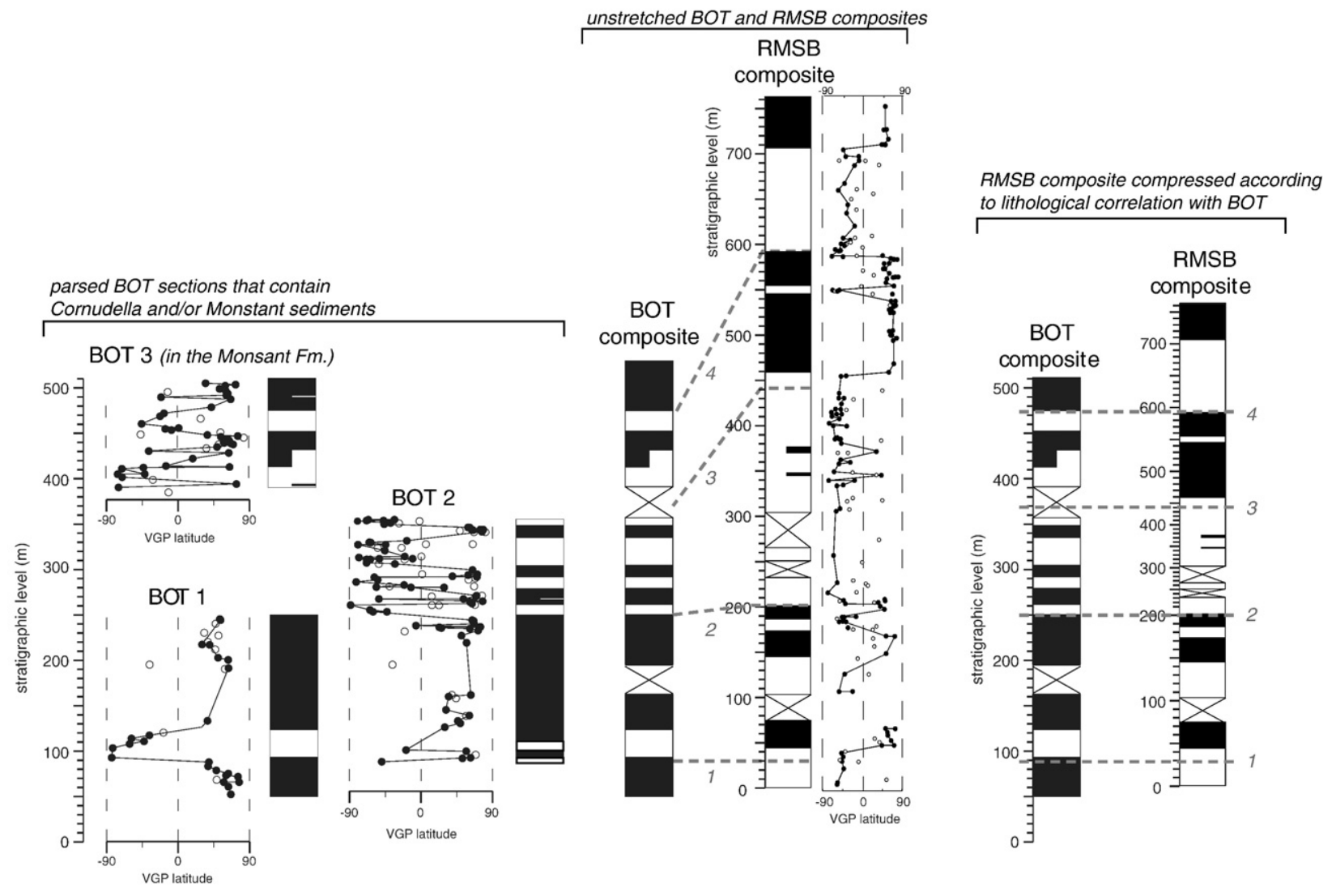

Fig. 1. Parsed LMPS for the BOT 1, BOT 2 and lower BOT 3 subsections (nomenclature from Swanson-Hysell and Barbeau, 2007) of the Bot composite LMPS reported in Jones et al. (2004) compared with the composite LMPS of the Rodamunts-Muntanya de Santa Bàrbara (RMSB) LMPS (Swanson-Hysell and Barbeau, 2007). Separation of the BOT 1 and BOT 2 subsections is based on Fig. S2 of Garcés et al. (2008-this issue) and personal communication (Garcés et al., pers. comm., 2008). Lithologic correlations detailed in the text are shown as dashed lines, and then used as constraints for the rightmost panel where the RMSB LMPS is linearly compressed between the correlated strata to facilitate comparison of polarity zones.

our techniques, which we employed in the absence of sufficient metadata for the Bot magnetostratigraphy reported in Jones et al. (2004).

In order to tie the magnetostratigraphy of Jones et al. (2004) to the lithostratigraphy of the Puig Cavaller area and to make intra-regional LMPS comparisons in our original manuscript, we requested geographic locations of sampled sites or at least interpreted chron boundaries from the authors. This information was not contained within Jones et al. (2004) but is required to minimize possible interpolation errors in LMPS comparisons. We received neither but did receive an annotated map and a composite stratigraphic section that indicated the extent of the individual sections that were used to build the composite Bot section stratigraphies (M. Garcés, pers. comm., 2006). As a result, our original comparison of seemingly correlative LMPS in the Puig Cavaller and Rodamunts regions required the stretching and resultant interpolation of components of the Jones et al. (2004) Bot LMPS. We concur with Garcés et al. (2008)-this issue that stretching of LMPS onto map imagery is an imperfect method of magnetostratigraphic comparison due to variations in topography and changes in structural dip, but given the available metadata, it was the best means of comparison, and an approach which we note Garcés et al. (2008-this issue) employ themselves (e.g., their Fig. 2). Despite the acknowledged inferiority of this technique, in this case the juxtaposition of these two LMPS is more reasonable than Garcés et al. (2008-this issue) suggest:

(1) As indicated by the site localities in Fig. 3 of Swanson-Hysell and Barbeau (2007), samples collected from the lower S5 section were collected within $\sim 15 \mathrm{~m}$ of the course of the Barranc de Sanxet tributary, whose northwest orientation is perpendicular to local strike. Given this orientation, the steady $\sim 10 \%$ gradient of that stretch of the tributary, and near homoclinal dips of the lower S5 section, ${ }^{2}$ direct projection of the lower BOT 2 subsection LMPS onto the topography adjacent to the lower S5 section is a reasonable alternative to the preferable lithostratigraphic correlation of individual sites or chron boundaries, which have yet to be published for the Bot magnetostratigraphy of Jones et al. (2004).

(2) Having juxtaposed these sections according to the map and stratigraphic section provided to us (M. Garcés, pers. comm., 2006), there was such a stark contrast between the polarity zonations of the two sections that no reasonable interpolation could eliminate the apparent diachroneity of the two sections. We employed this comparative technique for illustrative purposes and did not intend to imply any particular spatio-temporal (i.e., correlative) relationship between any horizons other than those indicated by our two correlation lines (see Fig. 3 of Swanson-Hysell and Barbeau, 2007).

In their comment, Garcés et al. (2008-this issue) admonish our correlation using the metadata they provided us (M. Garcés, pers. comm., 2006), which they now characterize as "rough mapped transects," and suggest that we should have used "lithostratigraphic boundaries" described in Jones et al. (2004) to identify their chron boundaries or

${ }^{2}$ Over the approximately $200 \mathrm{~m}$ of the lower S5 section we correlated with the lower BOT 2 subsection in our original contribution, thirteen structural measurements (Barbeau, 2003) indicate no statistical difference in the mean structural dip of $48^{\circ}$ through this interval - ten of the thirteen measurements are within $1 \sigma$, and the other three are well within $2 \sigma$ : there is no systematic change in dips suggesting the range of measurements is a function of standard sampling errors, not true variation. 


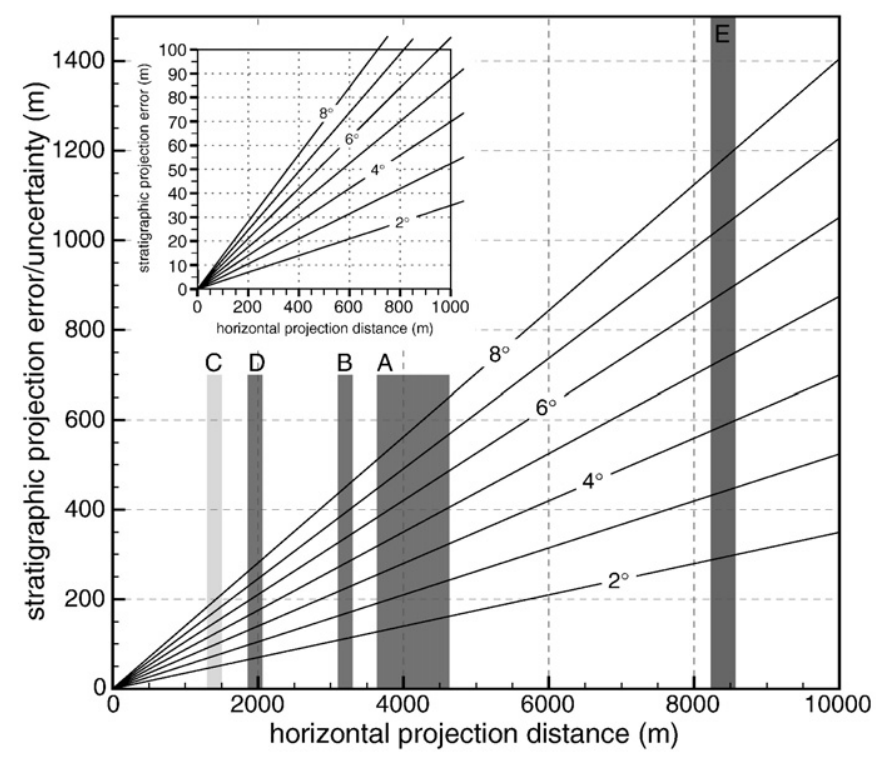

Fig. 2. Stratigraphic thickness errors resulting from erroneous projections across covered or eroded intervals. Box A indicates the range of stratigraphic thickness errors resulting from ignorance of the differences in depositional topography of fluviolacustrine and cobble-dominated alluvial-fan deposystems for projections from the edge of the Montsant Formation conglomerates to the top of the BOT 4 and BOT 5 subsections for a range of plausible angular errors (Blair and McPherson, 1994). Box B indicates the range of stratigraphic thickness errors resulting from projections across each of the poorly exposed BOT 4 and BOT 5 subsections used to compile the composite Bot LMPS of Jones et al. (2004). Box C depicts the range of stratigraphic thickness errors resulting from projections required by the composite RMSB LMPS (Swanson-Hysell and Barbeau, 2007). Box D depicts the range of stratigraphic thickness errors resulting from projections required by the composite LMPS of BOT 1, BOT 2 and lower BOT 3 subsections collected by Jones et al. (2004), and which reside completely within the Montsant Formation. Box E depicts the range of stratigraphic thickness errors resulting from projections required by the composite Bot LMPS of Jones et al. (2004).

sample sites (2008). First, we are perplexed as to how Garcés et al. (2008this issue) envisioned us achieving an accurate representation of their magnetostratigraphy using the suggested technique - with no viable geographic metadata describing the true localities of the sample sites of Jones et al. (2004) and only partially detailed lithologic information, there remains no way to comprehensively tie the Bot magnetostratigraphy to lithostratigraphy without interpolation between lithostratigraphic boundaries. Second, the lesser quality of the provided metadata (M. Garcés, pers. comm., 2006) was fully unbeknownst to us, as it represented a marked improvement upon the clearly erroneous and missing metadata in Jones et al. (2004). For example, the section locations of the upper part of the Bot magnetostratigraphy as now reported in Garcés et al. (Figs. 1 and S2) differ quite dramatically from that reported in Jones et al. (2004), which shows the magnetostratigraphic sampling ending within $0.5 \mathrm{~km}$ of the town of Bot while Fig. 1 of Garcés et al. (2008-this issue) now shows it to continue past Bot for an additional $3.8 \mathrm{~km}$. It is disappointing that Garcés et al. viewed their self-perceived imprecise metadata as a suitable response to our explicit request, thereby underscoring the importance of original publication of detailed positional metadata for all sampled sections and site locations.

\section{The diachroneity of the Montsant Formation?}

Our original contribution (Swanson-Hysell and Barbeau, 2007) focused on the premise that lithostratigraphic correlation between magnetostratigraphic sections two or less km apart appears tenable within the alluvial-fan conglomerates of the Montsant Formation, but that long-distance correlations present an apparent diachroneity when examined through the lens of magnetic polarity stratigraphy. Unfortu- nately, the map and stratigraphic column originally provided to us by M. Garcés (pers. comm., 2006) contradict the stratigraphic overlaps between the BOT 1 and BOT 2 subsections that Garcés et al. (2008-this issue) now reveal (their Fig. S2), thereby requiring a reconsideration of our original observations. However, herein we demonstrate that our original hypothesis remains viable. Following modification of our correlation in light of the provided metadata, the magnetic polarity stratigraphies reported in Jones et al. (2004) and Swanson-Hysell and Barbeau (2007) have discrepancies along lithologic horizons regardless of interpreted GPTS correlations, suggesting that the lithostratigraphy of alluvial-fan deposystems may indeed be significantly diachronous.

Garcés et al. (2008-this issue) establish a useful framework by detailing three lithologic marker beds that intersect the stratigraphy of the BOT 1 and BOT 2 sections (their Fig. 2). However, these correlations, while argued to be based on lithology in the text, are not properly correlated to the RMSB section (see Fig. 1 for our interpretation of the lithologic correlation). The lithologic correlations can be made as follows:

(1) A lowermost marker bed can be traced from $30 \mathrm{~m}$ in the RMSB section to $\sim 90 \mathrm{~m}$ in the BOT section.

(2) The corrected placement of the continuous conglomerate unit marked by the thick dotted line in Fig. 3 of Swanson-Hysell and Barbeau (2007), and as "2" in Fig. 2 of Garcés et al. (2008-this issue) in the BOT stratigraphy is a welcome constraint, but this lithologic marker intersects the RMSB at $205 \mathrm{~m}$ as opposed to $165 \mathrm{~m}$. Given that Garcés et al. (2008-this issue) indicate that this marker is equivalent to the lower dashed line of Fig. 3a of Swanson-Hysell and Barbeau (2007), we consider it odd that it is miscorrelated in the comment given that we indicated the exact location of each site in the RDM and S5 sections and their corresponding polarity.

(3) The resistant conglomerate bed that intersects the Bot stratigraphy at meter level 370 can be traced laterally to the RMSB section where it intersects meter level 440 (as opposed to meter level 400 suggested by Garcés et al. (2008-this issue)).

(4) An additional correlation constraint comes from the top of the Unit C of Jones et al. (2004) which is shown in Fig. S1 of Garcés et al. (2008-this issue), and intersects the Bot stratigraphy at meter level 470. This lithologic marker can be traced laterally to a position near the top of the S5 section (meter level 595 in the composite RMSB stratigraphy).

The revised lithologic constraints that are now possible with the corrected locations of the individual Bot sections remove one of the most dramatic discrepancies that was noted in our original contribution. This discrepancy was the juxtaposition of a thick zone of normal polarity in the Bot stratigraphy (between meter levels 120-225) next to a zone of reversed polarity in the S5 LMPS of the RMSB stratigraphy.

A revised lithostratigraphic correlation between the Bot and RMSB magnetostratigraphies is shown in Fig. 1. As detailed below in Sections 4, 6 and 7, we do not consider the Jones et al. (2004) magnetostratigraphic data from the distal Caspe and Mequinenza Formations to be of direct use to understanding Montsant chronostratigraphy and have simply considered the portions of the Bot magnetostratigraphy that were developed within the Cornudella and Montsant Formations for this revised correlation. The lithologic markers detailed above were used to adjust the RMSB composite in accordance with these correlations for the purpose of polarity comparison. While in some cases conflicts in polarity can be explained through gaps in the respective records (e.g., reversed polarity from meter levels 106-145 in the RMSB LMPS corresponds to a gap in data in the Bot LMPS; thin normal chrons between meter levels 260-310 of the Bot LMPS correspond to an interval with sparse data coverage in the RMSB LMPS), there remain conflicts in the polarity records such as across lithologic marker "4" that imply significant diachroneity of the alluvial-fan lithosomes. 


\section{Correlation between depositional systems}

There are inherent difficulties and uncertainties in developing a magnetostratigraphy through alluvial-fan strata due to the dominance of coarse-caliber sediment, the potential for erosion of previously deposited strata and the fact that more time may be 'missing' than represented in such a succession. However, we feel that the challenges of using data from distal strata and attempting to project such data into more proximal strata are also fraught with large uncertainties.

Garcés et al. (2008-this issue) imply that a correlation of the Jones et al. (2004) magnetostratigraphy from the distal fluvio-lacustrine sediments of the Caspe and Mequinenza Formations to the proximal conglomerates of the Montsant Formation is straightforward. They state that their correlation to the more proximal strata is made on the basis of total thickness, making the implicit assumptions of identical sedimentation rates, depositional geometries and histories in distal fluvio-lacustrine deposystems as in proximal alluvial fans. It is with these assumptions of equal thickness and chronostratigraphic equivalence that Garcés et al. (2008-this issue) justify juxtaposition of the magnetostratigraphy from the distal Caspe and Mequinenza Formations next to a lithostratigraphic section through the Montsant Formation at Puig Cavaller in Jones et al. (2004).

Modern alluvial-fan dimensional data indicate that cobble-dominated alluvial fans such as that preserved at Rodamunts (Barbeau, 2003) have average depositional slopes of $\sim 2-8^{\circ}$ (Blair and McPherson, 1994), and that the regional depositional slopes within any one fan can span a large range as indicated by the $2-22^{\circ}$ slopes measured on the Trollheim Fan (Blair and McPherson, 1992). Fluvio-lacustrine depositional systems have slopes $<<1^{\circ}$ (Blair and McPherson, 1994), indicating the significant difference in depositional topography between the Caspe-Mequinenza and Montsant Formations deemed correlatable by Jones et al. (2004) and Garcés et al. (2008-this issue). We consider the resulting 2-8 angular differences between the Caspe-Mequinenza and Montsant Formations to be minima due to the possibility of differential compaction of the weaker mudstone-dominated strata of the former formations compared to the mechanically strong carbonate-clast conglomerates of the latter. Neither Jones et al. (2004) or Garcés et al. (2008-this issue) report angular adjustments to correct for these differential depositional topographies; hence their projections should comprise large stratigraphic thickness errors. To quantify the range of possible magnitudes of these miscalculations, we compare the stratigraphic projection errors caused by neglecting the differences in depositional topographies in Fig. 2. Uncorrected projection over the 3.7-4.6 km horizontal distances between the featheredge of the Montsant Formation (near the middle of the BOT 3 subsection) and the tops of the BOT 4 and BOT 5 subsections yield stratigraphic thickness errors between 100 and $650 \mathrm{~m}$, depending on the actual difference in depositional topography (box A in Fig. 2).

The difficulty in projecting from one depositional system to another is further supported by Garcés et al.'s adjustment of the fossil locality at Gandesa that was included as part of Barberà et al.'s (2001) magnetobiostratigraphy for the eastern Ebro Basin - the correlation between the Bot magnetostratigraphy and the Gandesa locality is $220 \mathrm{~m}$ lower in the composite Bot LMPS of Garcés et al. (Fig. 2, this volume) than it was in Jones et al. (2004). While we do not dispute that the presence of late Oligocene mammal fossil localities in broadly equivalent strata is relevant to this discussion, the large flexibility inherent in such correlations across gently dipping strata from two distinctly different depositional systems weakens Garcés et al.'s argument that this correlation provides a firm constraint for tying meter level 740 of the composite Bot stratigraphy to the C10n-C9r reversal.

\section{Sedimentation rates}

Garcés et al. (2008-this issue) advance an argument that there is the potential for variable accommodation associated with deposition in proximal syn-kinematic strata. The argument that structural activity can lead to locally diminished accommodation (which we concur with) is fundamentally inconsistent with the approach of equating thickness and time from distal fluvio-lacustrine facies with more proximal alluvial-fan strata.

Contrary to Garcés et al.'s inference, we are well aware of the role that fold growth and thrust faulting plays in causing local structural uplift and locally decreasing accommodation in wedge-top depozones, and have considerable experience in studying this influence upon the stratigraphy of the immediate area (e.g., Barbeau, 2003). As indicated in our original contribution: "stratigraphic thickness variation and up-section dip decreases in the upper Montsant Formation of the Rodamunts region indicate syntectonic deposition of growth strata with deposition occurring atop a fault-propagation fold." Data presented in Barbeau (2003) further supports the interpretation of syntectonic deposition above meter-level 500 of the composite RMSB section, indicating that the gravel-dominated alluvial fans represented by meter levels $\sim 180-500$ were deposited in the most proximal foredeep depozone, whereas deposition in the uppermost part of the exposed Montsant Formation occurred in the wedge-top proper (DeCelles and Giles, 1996). We agree with the argument of Garcés et al. (2008-this issue) that accommodation is often reduced during wedge-top sedimentation. If this occurred, it would be expected that sedimentation rates would be affected upon the onset of wedge-top sedimentation - indicated by the presence of stratigraphic thickness variations, up-section decreases in structural dip and/or intraformational angular unconformities (Riba, 1976; Anadòn et al., 1986; Barbeau, 2003). In stark contrast, the reinterpretation of our data presented in Garcés et al. (2008-this issue) implies that the pre-wedge-top alluvial-fan conglomerates were deposited with a vertical aggradation rate that was $\sim 40 \%$ of the deposition rate of the underlying fluvial sediments and that upon arrival of fault propagation folds sedimentation rates increased by $220 \%$ - the opposite of the argument that Garcés et al. advance qualitatively.

While Garcés et al. (2008-this issue) themselves discuss the sedimentation rate changes resulting from local rock-uplift, they take issue with our original discussion of sedimentation rates as a tool with which to evaluate magnetostratigraphic correlation. Although interpretations of implied 1-D sedimentation rates alone are not a rigorous filter on magnetostratigraphic correlations, it is not unreasonable to assume some consistency between changes in facies, subsidence and sedimentation rates in the absence of evidence to the contrary. In our original contribution, we presented the hypothesis that the advancing thrust sheets of the Catalàn Coastal Ranges could have increased accommodation due to flexure-driven subsidence as well as delivered a higher flux of sediment to what was an internally drained, and therefore under-filled, intermontane basin. While this line of argumentation is criticized in Garcés et al.'s comment as "vague" and "general," this pattern is one that is commonly recognized in terrestrial foreland basins including previous work in the Ebro Basin itself (Zheng et al., 2000; López-Blanco et al., 2000; Charreau et al., 2006).

\section{Long-distance projections}

In addition to depicting our concerns about the difficulties and potentially hazardous assumption, of correlation between distal fluvio-lacustrine and proximal alluvial-fan strata, Fig. 2 demonstrates the importance of minimizing projection distances in compiling composite LMPS. According to the section transects indicated on Fig. 1 of Garcés et al. (2008-this issue), collection of the Jones et al. (2004) BOT 4 and BOT 5 LMPS subsections involved measuring relatively thin stratigraphic intervals over long distances. The BOT 4 subsection measures $255 \mathrm{~m}$ in thickness and was collected over a distance of $\sim 3250 \mathrm{~m}$ (box B in Fig. 2). The BOT 5 subsection measures $245 \mathrm{~m}$ in thickness and was collected over a distance of $\sim 3265 \mathrm{~m}$. In addition to yielding LMPS (which ideally is a one-dimensional, "paleo-vertical", 
dataset) collected over horizontal distances $\sim 13$ times as large as the stratigraphic intervals examined, this compilation procedure can lead to large projection uncertainties. Considering the low percentage of exposed stratigraphy in the BOT 4 and BOT 5 transects and the long distances between exposed outcrops of these sections (see Supplementary Material .kmz file for integration with orthophotographic imagery from Institut Cartogràfic de Catalunya via Google Earth), long, unconstrained projections across covered and/or eroded intervals are required in order to connect separate stratigraphic outcrops. Whereas such projections are unavoidable in the collection of stratigraphic data, Fig. 2 demonstrates how even small angular differences can lead to large stratigraphic uncertainties or errors when projected over long distances, and how minimization of projection distance yield more robust composite stratigraphic sections.

For the sake of demonstration, consider a conservative average dip measurement and projection error of $2^{\circ}$. This slight projection error over the distance of the BOT 4 and BOT 5 transects would lead to $~ 110$ $m$ of stratigraphic thickness uncertainty for each transect - more than $40 \%$ of the total thickness of each of the stratigraphic intervals (245$255 \mathrm{~m}$ ). Given these challenges, not to mention the possibility of small folds, faults or dip changes in the long covered/eroded sections, it is difficult to accept that the stratigraphic order of sites, let alone stratigraphic thicknesses, could be robustly compiled using such a technique. For comparison, we indicate on Fig. 2:

(a) the $\sim 1380 \mathrm{~m}$ transect distance and resultant projection errors that correspond with our collection of the entire $850 \mathrm{~m}$ of stratigraphic section used to compile our $760 \mathrm{~m}$ RMSB composite LMPS (Swanson-Hysell and Barbeau, 2007). Assuming a $2^{\circ}$ dip measurement and projection error, this leads to a total stratigraphic uncertainty or error of $40 \mathrm{~m}$, or $~ 3 \%$ (box C of Fig. 2).

(b) the $1960 \mathrm{~m}$ transect distance and resultant projection errors that correspond to the $580 \mathrm{~m}$ of section used to compile the composite LMPS constructed from BOT 1, BOT 2 and BOT 3 subsections that fully reside within the Montsant Formation (Jones et al., 2004; Garcés et al., 2008-this issue). Assuming a $2^{\circ}$ dip measurement and projection error, this leads to a total stratigraphic uncertainty or error of $60 \mathrm{~m}$, or $\sim 10 \%$ (box D of Fig. 2).

(c) the $\sim 8470 \mathrm{~m}$ of transect distance and resultant projection errors that correspond to the $1180 \mathrm{~m}$ of section used to compile the entire composite Bot LMPS (Jones et al., 2004; Garcés et al. 2008-this issue). Assuming a $2^{\circ}$ dip measurement and projection error, this leads to a total stratigraphic uncertainty or error of $296 \mathrm{~m}$, or $25 \%$ (box E of Fig. 2).

Considering these data in light of the lithostratigraphic and biostratigraphic data from the BOT 4 and BOT 5 subsections that Garcés et al. (2008-this issue) use to tie the composite Bot LMPS to the GPTS, it is difficult to put much confidence in the age model presented in Jones et al. (2004) and defended by Garcés et al. (2008-this issue).

\section{Conclusions}

Because of the exceptionally large proportions of covered or eroded intervals within the BOT 4 and BOT 5 subsections (naming convention from Swanson-Hysell and Barbeau, 2007), we do not consider the Jones et al. (2004) LMPS constructed from those strata to be sufficiently robust.

We consider the composite section comprised of the BOT 1, BOT 2 and lower BOT 3 subsections (ibid.) reported by Jones et al. (2004) as a feasible LMPS for the Montsant Formation near Puig Cavaller. However, because correlation of this LMPS to the GPTS requires an unproven spatio-temporal relationship with the Caspe and Mequinenza Formations of the BOT 4/BOT 5 LMPS, which are themselves less rigorous, the resulting age model for these data is less robust than presented by Jones et al. (2004) and Garcés et al. (2008-this issue). In light of new metadata presented by Garcés et al. (2008-this issue) and M. Garcés (pers. comm, 2008, and depicted in our Fig. 1), the inconsistencies in the Bot and RMSB polarity stratigraphies between lithostratigraphically correlative levels (Fig. 1) are slightly different than indicated in our original contribution (Swanson-Hysell and Barbeau, 2007). However, these inconsistencies persist and are suggestive of diachroneity of the strata. As in our original contribution, we refrain from providing an alternative correlation of the BOT 1-BOT 3 subsections to the GPTS without precise geographic location metadata for the Jones et al. (2004) sites. We encourage Garcés et al. to publish their site locations so that these data can be more robustly incorporated into the determination of the age of the Montsant Formation.

Garcés et al.'s alternative interpretation of the RMSB LMPS to the GPTS is based on a composite magnetostratigraphy that relies on: (1) the assumption that the Caspe and Mequinenza mudstones and limestones of BOT 4 and BOT 5 are equivalent with the upper Monsant Formation in terms of stratigraphic thickness and the timing of deposition, and (2) long-distance projections across covered and eroded intervals. In contrast, our data remains wholly within the Montsant Formation. Despite this advantage over the Caspe-Mequinenza-Montsant composite age models of Jones et al. (2004) and Garcés et al. (2008-this issue) for the Montsant Formation, we do not consider our original correlation to the GPTS final until corroborated with independent age control or additional high-resolution magnetostratigraphic work.

Finally, we consider the inclusion of detailed geographic locations as essential metadata that should be included with the publication of magnetostratigraphies. Without site localities or the geographic location of chron boundaries, it is difficult for reviewers to evaluate the robustness of composite LMPS and for future researchers to apply archived data precisely. If future scientists are unable to precisely locate themselves or their samples within an age model, what good is it?

\section{Appendix A. Supplementary data}

Supplementary data associated with this article can be found in the online version at doi:10.1016/j.epsl.2008.07.018.

\section{References}

Anadòn, P., Cabrera, L., Colombo, F., Marzo, M., Riba, O., 1986. Syntectonic intraformational unconformities in alluvial fan deposits, eastern Ebro Basin margins (NE Spain): Special Publication of the International Association of Sedimentologists, 8, pp. 259-271.

Barbeau, D.L. Jr., 2003. Application of growth strata and detrital-zircon geochronology to facies architecture and kinematic histories, (Ph.D. Dissertation), University of Arizona, 227pp.

Barberà, X., Cabrera, L., Marzo, M., Parés, J.M., Agustí, J., 2001. A complete terrestrial Oligocene magnetostratigraphy from the Ebro Basin, Spain. Earth Planet. Sci. Lett. $187,1-16$.

Blair, T.C., McPherson, J.G., 1992. The Trollheim alluvial-fan and facies model revisited. Geol. Soc. Am. Bull. 104, 762-769.

Blair, T.C., McPherson, J.G., 1994. Alluvial fans and their natural distinction from rivers based on morphology, hydraulic processes, sedimentary processes, and facies. J. Sediment. Res. A64, 451-490.

Charreau, J., Gilder, S., Chen, Y., Dominguez, S., Avouac, J.-P., Sen, S., Jolivet, M., Li, Y., Wang, W., 2006. Magnetostratigraphy of the Yaha section, Tarim Basin (China): 11 Ma acceleration in erosion and uplift of the Tian Shan mountains. Geology 34, 181-184.

DeCelles, P.G., Giles, K.A., 1996. Foreland basin systems. Basin Res. 8, 105-123.

Garcés, M., Cabrera, L., Roca, E., Gratacós, O., 2008. Comment on "The diachroneity of alluvialfan lithostratigraphy? A test case from southeastern Ebro basin magnetostratigraphy". Earth Planet. Sci. Lett. 275, 181-186 (this issue). doi:10.1016/j.epsl.2008.07.024.

Heizler, M., EARTHTIME Ar working group, 2008. Argon laboratory intercomparison efforts for the Earthtime initiative. Geophysical Research Abstracts, 10, EGU2008-A11478 .

Jones, M.A., Heller, P.L., Roca, E., Garcés, M., Cabrera, L., 2004. Time lag of syntectonic sedimentation across an alluvial basin: theory and example from the Ebro Basin, Spain: Basin Res. 16, 467-488.

López-Blanco, M., Piña, J., Marzo, M., 2000. Anatomy of regressive tracts in a regressive sequence set: Vilomara unit, Sant Llorenç del Munt, Ebro Basin, NE Spain. Sediment. Geol. 138, 143-159. 
Riba, O., 1976. Syntectonic unconformities of the Alto Cardener. Spanish Pyrenees: genetic interpretation. Sediment. Geol. 15, 213-233.

Swanson-Hysell, N., Barbeau Jr., D.L., 2007. The diachroneity of alluvial-fan lithostratigraphy? A test case from southeastern Ebro basin magnetostratigraphy, Earth Planet. Sci. Lett. 262, 343-362.
Westerhold, T., Röhl, U., 2008. The early Paleogene astronomic time scale - new insights into biological, climatic and tectonic events. Geophysical Research Abstracts 10, EGU2008-A-03115.

Zheng, H., Powell, C.M., An, Z., Zhou, J., Dong, G., 2000. Pliocene uplift of the northern Tibetan Plateau. Geology 28, 715-718. 